\title{
Effect of Foliar Application with Multi-Micronutrients and Polyamines on Productivity and Storeability of Valencia Oranges Abo-El-Ez, A. E. T. ${ }^{1}$; S. A. G. Elsayada ${ }^{2}$; E. E. H. Abdel All ${ }^{1}$ and I. F. A. E. Fayyad ${ }^{2}$ ${ }^{1}$ Dept. of Hort., Fac. of Agric., Sohag University, Sohag, Egypt. \\ ${ }^{2}$ Dept. of Citrus, Hort. Res. Instit., Agriculture Research Center, Giza, Egypt.
}

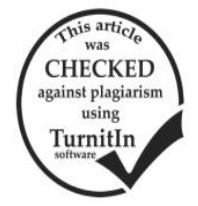

\section{ABSTRACT}

The present study was carried out during two successive seasons 2015 and 2016 on of Valencia orange trees (Citrus sinensis L. Osbeck) budded on Volkamer lemon (Citrus volkameriana L.) rootstock, grown in sandy soil under drip irrigation system, in a citrus orchard located in El-Kwamel farm, college of Agriculture, Sohag University, Egypt. The selected trees (33 tree) of Valencia orange cv. were set as a randomized complete block design (RCBD) with 3 replications. The target of this study was to investigate the effect of foliar spraying of multi-micronutrients $(1 \%$ B, $200 \mathrm{ppm} \mathrm{Zn}$ and $250 \mathrm{ppm} \mathrm{Fe})$ and three levels of putruscine (10-3, 10-5 and 10-7mM/Lit) individually or their combinations at full bloom and after ten days from fruit set on productivity and some quality parameters upon harvest as well as during storage at room (ambient) temperature for better marketability of Valencia orange without economical loss. It can be concluded that $10-$ $3 \mathrm{mM} /$ Lit (PUT) + Multi-micronutrients treatment gave the highest values of fruit set, retained fruit/tree, fruit weight (g), fruit juice weight $(\mathrm{g})$, fruit juice volume $(\mathrm{cm})$ and fruit peel thickness $(\mathrm{mm})$ of Valencia orange. As well as it gave the highest rate of total soluble solids (TSS) percentage, TSS/acid ratio and ascorbic acid (100g juice) and the lowest values of fruit decay percentage during storage period. This study suggested that 10-3mM/Lit (PUT) + Multi-micronutrients treatment may be consider a useful technology for improve productivity and some quality parameters upon harvest of Valencia orange trees. As well as, the same treatments to avoid the negative quality effects during fruit storage at room (ambient) temperature especially increase the rate of total soluble solids percentage, TSS/acid ratio and ascorbic acid (100g juice) for better marketability of Valencia orange fruits without economical loss.

Keywords: Valencia orange, Putruscine, Multi-micronutrient, Foliar spraying, Fruit storage.

\section{INTRODUCTION}

Citrus is a member of world's subtropical fruits and Rutaceae family. The importance of citrus fruits in order of high vitamin $\mathrm{C}$ and anti-cancer effects (Martí et al., 2007). Oranges are second fruit after apple that people consumed in all over the world.

Valencia orange trees grown at the new reclaimed soils such as sandy soil which is usually poor in their nutrients content, low organic matter and lower in catching water, with high nutrients leaching losses led to lower nutrient uptake by plant and has negative effect on vegetative growth, yield and fruit quality. Therefore, trees grown in this soil needs more attention in cultural practices such as fertilization, foliar spray with minerals and biofertilizers to enhance growth, yield and fruit quality. Foliar application of micronutrients like $\mathrm{Zn}, \mathrm{Cu}, \mathrm{Mn}, \mathrm{B}$ and $\mathrm{Fe}$ has advantages over soil application because of high effectiveness, rapid plant response, convenience and elimination of toxicity symptoms brought about by excessive soil accumulation of such nutrients (Obreza et al., 2010).

Micronutrient plays many complex roles in plant nutrition and plant production, while most of micronutrients participate in the functioning of number of enzyme systems, there is considerable variation in the specific functions of the micronutrients in plant and microbial growth processes, Micro-nutrients such as iron, zinc and boron are essential for different biological functions that might be attributed to tree yield and fruit quality (Shoeib, 2003). It is also increased resistance to disease and insect pests and improved drought tolerance (Tariq et al., 2007).

Boron as a micronutrient plays significant role in growth and productivity of citrus. It increases pollen grains germination, pollen tube elongation, consequently, fruit set $\%$ and total yield, cell division, biosynthesis and translocation of sugars water and nutrient uptake (GarciaPapi and Martinez, 2003, Abd-Allah, 2006 and Ahmad et al., 2009). The Boron deficiency is mainly found in acidic and sandy soils, and those with low soil organic matter. Plant species differ dramatically in B mobility, and may be classified into species with restricted B mobility and those in which B is highly mobile (Brown and Shelp, 1997).

Also, zinc is another important microelement essential for plants due to its involvement in the synthesis of tryptophan which is a precursor of indole acetic acid synthesis. $\mathrm{Zn}$ is required for the activity of various enzymes, such as dehydrogenases, aldolases, isomerases, transphosphorylases, RNA and DNA polymerases (Swietlik, 1999). It has important role in starch metabolism, and acts as co-factor for many enzymes, affects photosynthesis reaction, nucleic acid metabolism and protein biosynthesis (Marschner, 1996, Badu and Singh, 2001, Mengel et al., 2001, Dickinson et al., 2003, Alloway, 2008 and Hassan et al., 2010). However, in the light of better fruit quality development, $\mathrm{Zn}$ holds more significance besides imparting sustainability in production/ productivity by reducing the fruit drop (Malik et al., 1999), and granulation (Kaur et al., 1990).

Free polyamines (PAs) such as putrescine (Put), spermine $(\mathrm{Spm})$ and spermidine (Spd) are polycationic compounds of low molecular weight that have been shown to play an important role as growth regulators in different stages of growth and development of buds, flowers and fruits in citrus, grapes and plum trees (Tiburcio, 1997, Eskandari, 1999 and Tonon et al., 2004).

Dibble et al. (1988) stated that deterioration of fruit quality physiologically correlates with reduction of polyamine (PA) content in the ripening fruits and increase in ethylene production. Polyamines are biological compounds of low molecular weight in their free forms which act as anti-senescent agents, delay ethylene production, reduce rate of respiration, increase fruit firmness, induce mechanical resistance, reduce chilling symptoms and retard colour changes (Valero et al., 2002). It has been shown that during post-harvest life of several fruits, PAs reduced fruit softness, fruit colour, physiological weight loss and delaying ripening (Malik et al., 2003, Malik and Singh, 2005, Aman and Zora, 2006, Jawandha et al., 2012 and Mohammad et al., 2013). 
With due attention to an importance of citrus as one of the most important horticulture and exports crops of Egypt and in order to increase shelf life and quality improvement of citrus, research in this field is necessary therefore, the present study aimed to investigate the effect of foliar spraying of multi-micronutrient (iron, zinc and boron) and polyamine (Putrescine) individually or their combinations during full bloom and after ten days from fruit set on leaf mineral content, productivity, some quality parameters upon harvest as well as during storage at room (ambient) temperature for better marketability of Valencia orange fruits without economical loss.

\section{MATERIALS AND METHODS}

The present study was carried out during two successive seasons 2015 and 2016 on 10- years old Valencia orange trees (Citrus sinensis L. Osbeck) budded on Volkamer lemon (Citrus volkameriana L.) rootstock, grown in sandy soil and spaced $5 \times 5 \mathrm{~m}$ apart subjected to drip irrigation system, in a citrus orchard located in El-Kwamel farm, college of Agriculture, Sohag University, Egypt, is subject to mild winters and warm and dry summer. All the chosen trees healthy, nearly uniform in shape and size and received the same horticulture practices.

Table 1. Analysis of orchard experimental soil at El-Kwamel Farm, College of Agriculture, Sohag University, Egypt.

\begin{tabular}{lcccccc}
\hline \multirow{2}{*}{ Physical properties } & Sand & Silt & Clay & $\mathbf{C a C o}_{\mathbf{3}}(\mathbf{\%})$ & $\mathbf{O . M}(\mathbf{\%})$ & Texture \\
\cline { 2 - 7 } & 89.60 & 5.85 & 4.55 & 3.10 & 0.07 & Sandy \\
\hline \multirow{3}{*}{ Chemical composition } & $\mathrm{pH}$ & $\mathrm{EC} \mathrm{dSm}-1$ & $\mathrm{~N} \%$ & $\mathrm{P} \mathrm{ppm}$ & $\mathrm{K} \mathrm{ppm}$ & $\mathrm{SO}_{4} \mathrm{meq} / \mathrm{L}$ \\
\cline { 2 - 7 } & 8.70 & 1.20 & 0.05 & 0.80 & 185.0 & 3.90 \\
\cline { 2 - 7 } & $\mathrm{Na} \mathrm{meq} / \mathrm{L}$ & $\mathrm{K} \mathrm{meq} / \mathrm{L}$ & $\mathrm{Ca} \mathrm{meq} / \mathrm{L}$ & $\mathrm{Mg} \mathrm{meq} / \mathrm{L}$ & $\mathrm{Cl} \mathrm{meq} / \mathrm{L}$ & $\mathrm{Hco} \mathrm{meq}_{3} / \mathrm{L}$ \\
\cline { 2 - 7 } & 0.54 & 0.37 & 8.62 & 3.28 & 6.00 & 3.00 \\
\hline
\end{tabular}

Climatic factors data: Mean monthly temperature and relative humidity (maximum and minimum) for ElKwamel region (farm location) during 2014, 2015 and

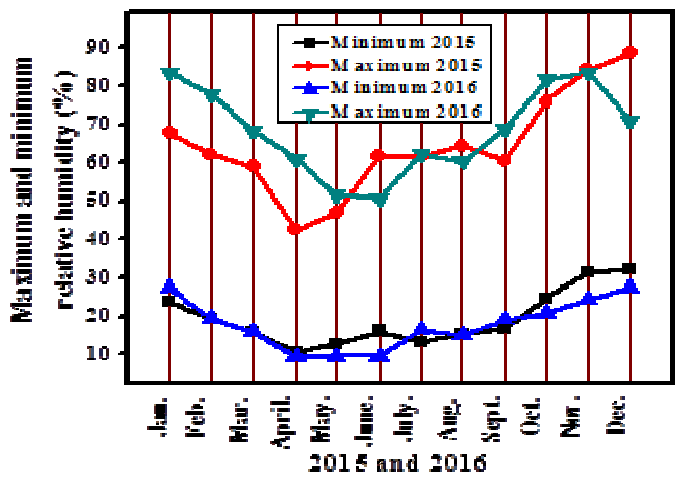

Figure 1. Meteorological data (mean monthly maximum and minimum temperature and relative humidity) for 2015 and 2016 under Sohag climatic conditions.

Experimental work: To improve productivity and storability of Valencia orange trees, multi-micronutrient i.e., boron (B) as liquid borost $15 \%$, zinc ( $\mathrm{Zn})$ as microgreenchelat zinc $15 \%$ and iron $(\mathrm{Fe})$ as strong chelat iron $12 \%(1 \% \mathrm{~B}, 200 \mathrm{ppm} \mathrm{Zn}$ and $250 \mathrm{ppm} \mathrm{Fe})$ and three levels of putruscine (PUT) "1,4- Diaminobutane, molocular weight 88.15 and linear formula $\mathrm{NH}_{2}\left(\mathrm{CH}_{2}\right)$ $\mathrm{NH}_{2}$ " $\left(10^{-3}, 10^{-5}\right.$ and $\left.10^{-7} \mathrm{mM} / \mathrm{Lit}\right)$ were sprayed either alone or in combinations on Valencia orange trees (30 tree) with (3 tree) control (water spray)during full bloom stage or after ten days from fruit set in early morning,during each season. All treatments were applied to run off by using compression sprayers (5L solution/tree) at the previously mentioned times. Wetting agent Tween 20 (1\%) was added to all treatments to reduce the surface tension and increase the contact angle of sprayed droplets.

Treatments: The details of the treatments composition were as follow:

$\left(\mathrm{T}_{1}\right)$ Control (water spray)

(T2) Spraying multi-micronutrients (1\% B, $200 \mathrm{ppm} \mathrm{Zn}$ and $250 \mathrm{ppm} \mathrm{Fe}$ ) once at full bloom stage.

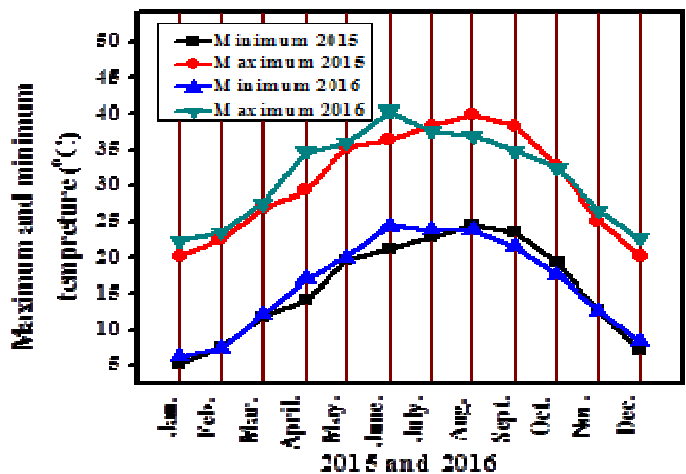

2016 seasons (according to Metrology Organization in Cairo) are shown in figure (1).

(T3, T4 and T5) Spraying 10-3 mM/Lit (PUT), spraying 10-5 $\mathrm{mM} /$ Lit (PUT) and spraying $10-7 \mathrm{mM} / \mathrm{Lit}$ (PUT), once at full bloom stage.

(T6, T7 and T8) Spraying 10-3 mM/Lit (PUT) + multimicronutrients (1\% B, $200 \mathrm{ppm} \mathrm{Zn}$ and $250 \mathrm{ppm} \mathrm{Fe})$, spraying $10-5 \mathrm{mM} / \mathrm{Lit}$ (PUT) + multi-micronutrients $(1 \% \mathrm{~B}, 200 \mathrm{ppm} \mathrm{Zn}$ and $250 \mathrm{ppm} \mathrm{Fe})$ and spraying 10-7 mM/Lit (PUT) + multi-micronutrients $(1 \% \mathrm{~B}$, $200 \mathrm{ppm} \mathrm{Zn}$ and $250 \mathrm{ppm} \mathrm{Fe}$ ) once at full bloom stage.

(T9, T10 and T11) Spraying 10-3 mM/Lit (PUT) + multimicronutrients (1\% B, $200 \mathrm{ppm} \mathrm{Zn}$ and $250 \mathrm{ppm} \mathrm{Fe})$, spraying 10-5 mM/Lit (PUT) + multi-micronutrients $(1 \% \mathrm{~B}, 200 \mathrm{ppm} \mathrm{Zn}$ and $250 \mathrm{ppm} \mathrm{Fe})$ and spraying $10-7 \mathrm{mM} / \mathrm{Lit}$ (PUT) + multi-micronutrients $(1 \% \mathrm{~B}$, $200 \mathrm{ppm} \mathrm{Zn}$ and $250 \mathrm{ppm} \mathrm{Fe}$ ) once at full bloom and after ten days from fruit set stage.

Experimental design:

33 tree of Valencia orange cv. Were selected and set as a randomized complete block design (RCBD) with 3 replicates for analyses. During storage, the three replicates 
represented by 5 fruits for each treatment and taken to assess their quality parameters.

Data were recorded for the following parameters:

1. Productivity:

a. Fruit set and retention percentage: Ten shoots oneyear-old per each-tree (replicate) were selected and tagged at random, total number of flowers per shoot was counted at full bloom and fruit set was counted after one month from full bloom stage. The average number of fruits per shoot were recorded at the time of harvesting and calculated as percentages. Percent fruit set (FS \%) and fruit retention (FR \%) were calculated by the following formula:

\section{Number of fruitlets/shoot at set time}

F.S. $(\%)=$
Number of flowers/shoot at full bloom $\mathbf{x} 100$

Number of fruits at harvesting period

\section{F. R. $(\%)=$}

b. Fruit yield (Kg/tree): The total yield per tree $(\mathrm{kg})$ was obtained at harvest period when the fruits reached a peak in peel color and TSS in the control treatment reached $10.3 \%$ to $11.0 \%$ (Bai et al., 2009), fruits were picked from all treated trees on $9^{\text {th }}$ and $5^{\text {th }}$ December 2015 and 2016 seasons, respectively, fruits per tree were counted and weighted to estimate the yield/ tree $(\mathrm{kg})$.

c. Fruit yield increase or decrease (\%): Fruit yield increment or reduction was calculated as percentage through the following equation:

- fruit yield (kg)/control

Fruit yield increment or reduction $(\%)=$ Fruit yield (kg)/treatment

\section{Fruits quality:} ruit yield (kg)/control

At harvest time, five fruits from each selected tree (replicate) were chosen randomly to determine the following physic-chemical traits which included fruit weight $(\mathrm{g})$, fruit peel thickness $(\mathrm{cm})$, fruit Juice volume $(\mathrm{cm})$, fruit total soluble solids percentage (TSS\%), fruit TSS/acid ratio and fruit ascorbic acid (100g juice) content upon harvest. Enough number of fruits from each replicate were harvested, packed in cardboard boxes. They were sorted out for shape, size, and color intensity and stored at room (ambient) temperature $\left(20 \pm 2{ }^{\circ} \mathrm{C}\right.$ and $85 \pm 2 \% \mathrm{R}$. H. $)$ for 21 days. The analyses were performed to determine fruit quality which included fruit weight loss (\%), fruit decay (\%), TSS (\%),TSS/acid ratio and Ascorbic acid ( $100 \mathrm{~g}$ juice)every seven days up to end of the storage periods.

a. Fruit physical characteristics:

1. Fruit weight (g): It was determined by weighting the fresh fruit samples (15 fruit) and the average fruit weight were recorded in (g.).

2. Peel thickness (mm): Peel thickness of five fruits per replicate were measured using Averner Caliper and the averages were recorded in millimeters.

3. Fruit Juice volume (ml):Selected fruit were peeled by hand in the laboratory, then, the average of fruit Juice volume $(\mathrm{ml})$ were calculated.
4. Fruit weight loss: In order to determine fruit weight (FW) loss during the storage period, five fruit from each replicate were separated at the beginning of storage and weighed. Fruit weight loss was then measured weekly through the following equation:

Fruit weight loss $(\%)=$

F.W. before storage $-\mathbf{F}$.W. after storage

F.W. before storage

Weight loss for each replicate and each treatment was calculated as percentage.

5. Fruit decay percentage:Unmarketable fruits including pathological or physiological disorders were counted and relative to the initial number of fruits per each sample and calculated as a percentage for each replicate and treatment too through the following equation:

Fruit weight loss $(\%)=$

Number of decayed fruits at the time of sampling

$$
\text { Initial number of fruits }
$$

b. Fruit chemical content:

1. Total soluble solids percentage (TSS \%): Total soluble solids (TSS \%) was measured in the juice by using handy refractometer. Total acidity was determined by titration with $\mathrm{Na} \mathrm{OH}$ at $0.1 \mathrm{~N}$ and phenolphthalein as an indicator, and then expressed as gram citric acid/ $100 \mathrm{ml}$ juice, according to A.O.A.C. (1985).

2. TSS/acid ratio: TSS/acid ratio was estimated mathematically by dividing the value of TSS by titrable acidity.

3. Ascorbic acid (V.C) $\mathbf{m g} / \mathbf{1 0 0 g}$ juice): Ascorbic acid content (mg/100 ml juice) was determined according to the method given in A.O.A.C. (2000).

Statistical analysis:

All data collected were subjected to statistical analysis of variance (ANOVA) and significant difference among means was determined according to (Snedecor and Cochran, 1972). In addition significant difference among means were distinguished according to the Duncan's, multiple test range (Duncan, 1955) whereas, capital and small letters were used for differentiating the values of specific and interaction effects of investigated factors, respectively.

\section{RESULTS AND DISCUSSION}

1. Effect of multi-micronutrient and putruscine application alone or in combination at different concentrations on productivity:

a- Fruit set and fruit retention (\%):

Concerning the fruit set percentage data preformed that, there were insignificant differences between all treatments with respect to the fruit set percentage in the first season. While in the second season multimicronutrient, putrescine and putrescine plus Multimicronutrient treatments significantly increased the fruit set percentage more than that of control. The highest fruit set percentage in both seasons were recorded for 10-7 $\mathrm{mM} /$ Lit (PUT) + Multi-micronutrient treatment with percentages $(100.00$ and 100.00) in both season, respectively Table (2). 
Similar results were proved by Harhash and AbdelNasser (2001), Jeyakumar et al. (2001), Slavki et al. (2001) and Sarrwy et al. (2012) they stated that using boron was very beneficial in stimulating fruit setting in citrus and other fruit crops. Also, Hafez and El-Metwally (2007) found that $\mathrm{Zn}$ treatments promote fruit set in Washington navel orange. Likewise, Tariq et al., (2007) Khan et al. (2012) and Baghdady et al. (2014) indicated that foliar spraying of with Chelated zinc and boron significantly increased fruit set $\%$ in citrus and other fruit crops. Furthermore, Sajid et al., (2010) concluded that \% fruit set was not significantly affected by foliar spray of $\mathrm{Zn}$ and B alone or either in combination in sweet orange. In addition, Bioniel and Protacio (2002), Malik and Singh (2006) and Abd El-Migeed et al., (2013) found that increases in fruit set have been obtained with polyamines (putrescine) in citrus and other fruit crops.

Table 2. Effect of multi-micronutrient and putrescine application alone or in combination at different concentrations on percentage of fruit set and retention of Valencia oranges during 2015 and 2016 growing seasons.

\begin{tabular}{lcccc}
\hline \multirow{2}{*}{ Treatments } & \multicolumn{2}{c}{ Fruit set (\%) } & \multicolumn{2}{c}{ Fruit retention (\%) } \\
\cline { 2 - 5 } & $\mathbf{2 0 1 5}$ & $\mathbf{2 0 1 6}$ & $\mathbf{2 0 1 5}$ & $\mathbf{2 0 1 6}$ \\
\hline Control & $90.69^{\mathrm{A}}$ & $83.70^{\mathrm{A}}$ & $85.40^{\mathrm{A}}$ & $64.40^{\mathrm{B}}$ \\
Multi-micronutrient & $87.38^{\mathrm{ABC}}$ & $65.67^{\mathrm{AB}}$ & $50.98^{\mathrm{A}}$ & $74.47^{\mathrm{B}}$ \\
$10^{-3} \mathrm{~m} \mathrm{M} /$ Lit (PUT) & $76.77^{\mathrm{BC}}$ & $72.25^{\mathrm{AB}}$ & $55.95^{\mathrm{A}}$ & $74.73^{\mathrm{B}}$ \\
$10^{-5} \mathrm{mM} /$ Lit (PUT) & $86.60^{\mathrm{ABC}}$ & $81.10^{\mathrm{AB}}$ & $46.76^{\mathrm{A}}$ & $71.55^{\mathrm{B}}$ \\
$10^{-7} \mathrm{mM} /$ Lit (PUT) & $79.50^{\mathrm{ABC}}$ & $75.19^{\mathrm{AB}}$ & $77.55^{\mathrm{A}}$ & $94.01^{\mathrm{AB}}$ \\
$10^{-3} \mathrm{mM} /$ Lit (PUT) + Multi-micronutrient & $81.65^{\mathrm{ABC}}$ & $74.81^{\mathrm{AB}}$ & $90.18^{\mathrm{A}}$ & $95.0^{\mathrm{A}}$ \\
$10^{-5} \mathrm{mM} /$ Lit (PUT) + Multi-micronutrient & $82.19^{\mathrm{ABC}}$ & $72.54^{\mathrm{AB}}$ & $57.68^{\mathrm{A}}$ & $70.65^{\mathrm{B}}$ \\
$10^{-7} \mathrm{mM} /$ Lit (PUT) + Multi-micronutrient & $75.79^{\mathrm{C}}$ & $56.82^{\mathrm{B}}$ & $65.8^{\mathrm{A}}$ & $88.33^{\mathrm{B}}$ \\
$10^{-6} \mathrm{mM} /$ Lit (PUT) + Multi-micronutrient & $88.29^{\mathrm{ABC}}$ & $78.58^{\mathrm{AB}}$ & $43.04^{\mathrm{A}}$ & $50.94^{\mathrm{B}}$ \\
$10^{-10} \mathrm{mM} /$ Lit (PUT) + Multi-micronutrient & $90.36^{\mathrm{AB}}$ & $81.43^{\mathrm{AB}}$ & $53.47^{\mathrm{A}}$ & $70.94^{\mathrm{B}}$ \\
$10^{-14} \mathrm{mM} /$ Lit (PUT) + Multi-micronutrient & $83.49^{\mathrm{ABC}}$ & $81.42^{\mathrm{AB}}$ & $57.27^{\mathrm{A}}$ & $63.53^{\mathrm{B}}$ \\
\hline
\end{tabular}

Mean separation within treatments of the Valencia oranges according to L.S.D. at 0.05 level.

In regard to the fruit retention percentage data preformed that, there were insignificant differences between all treatments in the first season with respect to fruit number/tree. Whereas, in the second season $10^{-}$ ${ }^{3} \mathrm{mM} /$ Lit $\quad$ (PUT) + Multi-micronutrient treatment significantly increased the fruit retention percentage more than that of other treatments. The trees were treated with $10^{-3} \mathrm{mM} /$ Lit (PUT) + Multi-micronutrient foliar spray resulted in the maximum increase in retained fruit/tree (90.18 and 95.0) in both seasons, respectively, compared with other treatments including the control.

These results are in accordance with those reported by Hafez and El-Metwally (2007), Tariq et al. (2007), Khan et al. (2012), Sarrwy et al. (2012) and Yadav et al.(2013) they proved that foliar spraying with micronutrients have important role in fruit retention in citrus and other fruit crops. Besides, Singh and Janes (2000), Bioniel and Protacio (2002), Malik and Singh (2006), Kassem et al. (2011) and Abd El-Migeed et al. (2013) indicated that exogenous application of polyamine improved fruit retention in citrus and other fruit crops.

b. Yield (Kg/tree) and yield increase or decrease (\%).

Concerning the Yield ( $\mathrm{Kg} /$ tree) data preformed that, there were significant differences between different treatments with respect to the yield $(\mathrm{Kg} /$ tree) in both seasons. The highest values achieved by $10^{-3} \mathrm{mM} / \mathrm{Lit}$ (PUT) + Multi-micronutrient treatment with (32.77 and $35.36 \mathrm{Kg} /$ tree) in both seasons, respectively as shown in Table (3).

These results were coincide with those obtained by Dawoodet al. (2000), Ram and Bose (2000), EL-Baz (2003), Hafez and El-Metwally (2007), Tariq et al. (2007), Abd El-Mottyet al.(2010), Sajid et al. (2010), Hanafy Ahmed et al. (2012), Kaziet al. (2012), Khan et al. (2012), Sarrwy et al.(2012), Yadav et al. (2013), Abd El-Motty and Orabi (2014), Ashraf et al. (2014), Baghdadyet al.(2014) Salama (2015),Sayyad-Amin et al. (2015)) and Gurung et al. (2016). They concluded that foliar spraying of micronutrients (boron and zinc) increased the yield and the combined spraying of them was most effective in improving the fruit yield / tree in citrus and other fruit crops. In addition, Ashraf et al. (2014) indicated that application of zinc improves the citrus fruit yield and this might be due to involvement of zinc in photosynthesis, activation of enzyme systems, protein synthesis and translocation carbohydrate. In addition, Ali et al. (2010), Kassem et al. (2011), Abd El-Migeed et al. (2013) and Kamiab et al. (2015) found that increases in yield have been obtained with polyamines (putrescine) in citrus and other fruit crop.

As for the fruit yield increase or decrease percentage data revealed that, similar trend was observed regarding the effect of treatments on fruit yield increase or decrease percentage, since the trees were treated with $10^{-}$ ${ }^{3} \mathrm{mM} /$ Lit (PUT) + Multi-micronutrient showed to be the superior treatment on fruit yield increase (65.27 and 148.30) than other tested treatments in both seasons, respectively.

In terms of yield, Shoeib and El-Sayed (2003) pointed out that micronutrients such as iron, zinc and boron are essential for different biological functions that might be attributed to tree yield and fruit quality. Besides, boron increases pollen grains germination, pollen tube elongation, consequently, fruit set $\%$ and total yield, cell division, biosynthesis and translocation of sugars water and nutrient uptake (Garcia-Papi and Martinez, 2003, AbdAllah, 2006 and Ahmad et al., 2009). Zn is another important microelement essential for plants due to its involvement in the synthesis of tryptophan which is a precursor of indole acetic acid synthesis. 
Also, $\mathrm{Zn}$ is required for the activity of various enzymes, such as dehydrogenases, aldolases, isomerases, transphosphorylases, RNA and DNA polymerases (Swietlik, 1999). It has important role in starch metabolism, and acts as co-factor for many enzymes, affects photosynthesis reaction, nucleic acid metabolism and protein biosynthesis (Badu and Singh, 2001, Mengel et al., 2001, Dickinson et al., 2003, Alloway, 2008 and Hassan et al. 2010).

Polyamines play different roles in the plant such as control of the flowering, fruit set, growth and development of fruit, ovary evaluation, pollen germination and growth of pollen tube (Tonon et al., 2004).

Table 3. Effect of multi-micronutrient and putrescine application alone or in combination at different concentrations on fruit yield $(\mathrm{Kg} / \mathrm{tree})$ and percentage of fruit yield increase or decrease of Valencia oranges during 2015 and 2016 growing seasons.

\begin{tabular}{lcccc}
\hline \multirow{2}{*}{ Treatments } & \multicolumn{2}{c}{ Yield (Kg/tree) } & \multicolumn{2}{c}{ Yield increase or decrease (\%) } \\
\cline { 2 - 5 } & $\mathbf{2 0 1 5}$ & $\mathbf{2 0 1 6}$ & $\mathbf{2 0 1 5}$ & $\mathbf{2 0 1 6}$ \\
\hline Control & $19.83^{\mathrm{D}}$ & $14.06^{\mathrm{F}}$ & $1.00^{\mathrm{D}}$ & $1.00^{\mathrm{F}}$ \\
Multi-micronutrient & $23.15^{\mathrm{CD}}$ & $24.33^{\mathrm{BCD}}$ & $16.75^{\mathrm{CD}}$ & $72.02^{\mathrm{BCD}}$ \\
$10-3 \mathrm{~m} \mathrm{M} /$ Lit (PUT) & $26.26^{\mathrm{BC}}$ & $27.59^{\mathrm{BC}}$ & $32.78^{\mathrm{BC}}$ & $98.30^{\mathrm{BC}}$ \\
$10-5 \mathrm{mM} /$ Lit (PUT) & $22.22^{\mathrm{CD}}$ & $22.38^{\mathrm{CD}}$ & $12.06^{\mathrm{CD}}$ & $62.66^{\mathrm{CD}}$ \\
$10-7 \mathrm{mM} /$ Lit (PUT) & $28.33^{\mathrm{AB}}$ & $26.52^{\mathrm{BCD}}$ & $42.56^{\mathrm{B}}$ & $92.16^{\mathrm{BCD}}$ \\
$10-3 \mathrm{mM} /$ Lit (PUT) + Multi-micronutrient & $32.77^{\mathrm{A}}$ & $35.36^{\mathrm{A}}$ & $65.27^{\mathrm{A}}$ & $148.30^{\mathrm{A}}$ \\
$10-5 \mathrm{mM} /$ Lit (PUT) + Multi-micronutrient & $23.03^{\mathrm{CD}}$ & $20.59^{\mathrm{DE}}$ & $16.18^{\mathrm{CD}}$ & $48.95^{\mathrm{DE}}$ \\
$10-7 \mathrm{mM} /$ Lit (PUT) + Multi-micronutrient & $22.00^{\mathrm{CD}}$ & $15.59^{\mathrm{EF}}$ & $10.82^{\mathrm{CD}}$ & $10.01^{\mathrm{EF}}$ \\
$10-6 \mathrm{mM} /$ Lit (PUT) + Multi-micronutrient & $23.34^{\mathrm{CD}}$ & $25.19^{\mathrm{BCD}}$ & $17.88^{\mathrm{CD}}$ & $82.61^{\mathrm{BCD}}$ \\
$10-10 \mathrm{mM} /$ Lit (PUT) + Multi-micronutrient & $22.51^{\mathrm{CD}}$ & $29.41^{\mathrm{B}}$ & $13.66^{\mathrm{CD}}$ & $111.60^{\mathrm{AB}}$ \\
$10-14 \mathrm{mM} /$ Lit (PUT)+ Multi-micronutrient & $22.66^{\mathrm{CD}}$ & $22.80^{\mathrm{CD}}$ & $14.23^{\mathrm{CD}}$ & $64.99^{\mathrm{CD}}$ \\
\hline
\end{tabular}

Mean separation within treatments of the Valencia oranges according to L.S.D. at 0.05 level.

2. Effect of multi-micronutrient and putrescine application alone or in combination at different concentrations on fruit quality.

a. Fruit physical characteristics:

1. Fruit weight (g), peel thickness $(\mathrm{mm})$ and juice volume (cm):

Concerning the fruit weight $(\mathrm{g})$ data preformed that, there were significant differences between different treatments with respect to the fruit weight $(\mathrm{g})$ in both seasons. $10^{-3} \mathrm{mM} / \mathrm{Lit}$ (PUT) + Multi-micronutrient treatment gave the maximum values (245.80) of fruit weight $(\mathrm{g})$ of Valencia orange when compared with other treatments including control in the first season. Meanwhile, in the second season $10^{-10} \mathrm{mM} /$ Lit (PUT) + Multimicronutrient treatment gave the maximum values (234.90), presented in Table (4).
These results were in agreement with those obtained by Qin and Qin (1996) and Rodríguez et al. (2005) they stated that spraying with boron achieved the highest fruit weight of mandarin, orange. Also, Yadav et al. (2013) proved that foliar spraying with multimicronutrient $(\mathrm{B}, \mathrm{Zn}$ and $\mathrm{Fe})$ was the promising treatment for improvement of fruit weight of peach. As well as, Delgado et al. (1999) Fruit weight was greatly enhanced in response to application of boron. This is attributed to the great mobilization of $\mathrm{B}$ in olive trees during flowering and fruit development. In addition, Baghdady et al. (2014) indicated that foliar spraying of Valencia orange trees with Chelated calcium, Chelated zinc and boron significantly increased fruit weight. Besides, Ali et al. (2010), Ayad et al. (2011), Abd El-Migeed et al. (2013) and Raeisi et al. (2013) found that spraying putrescine at full bloom increased fruit weight of other fruit crops.

Table 4. Effect of multi-micronutrient and putrescine application alone or in combination at different concentrations on fruit weight $(\mathrm{g})$,peel thickness $(\mathrm{mm})$ and juice volume $(\mathrm{cm})$ of Valencia oranges during 2015 and 2016 growing seasons.

\begin{tabular}{|c|c|c|c|c|c|c|}
\hline \multirow{2}{*}{ Treatments } & \multicolumn{2}{|c|}{ Fruit weight (g) } & \multicolumn{2}{|c|}{ Fruit peel thickness(mm) } & \multicolumn{2}{|c|}{ Fruit juice volume (cm) } \\
\hline & 2015 & 2016 & 2015 & 2016 & 2015 & 2016 \\
\hline Control & $194.50^{\mathrm{F}}$ & $161.50^{\mathrm{EF}}$ & $3.63^{\mathrm{BC}}$ & $2.87^{\mathrm{C}}$ & $85.23^{\mathrm{E}}$ & $70.30^{\mathrm{E}}$ \\
\hline Multi-micronutrient & $202.70^{\mathrm{EF}}$ & $165.60^{\mathrm{EF}}$ & $3.73^{\mathrm{ABC}}$ & $3.07^{\mathrm{BC}}$ & $102.00^{\mathrm{C}}$ & $86.00^{\mathrm{AB}}$ \\
\hline $10^{-3} \mathrm{~m} \mathrm{M} / \mathrm{Lit}(\mathrm{PUT})$ & $243.20^{\mathrm{AB}}$ & $191.70^{\mathrm{BC}}$ & $4.10^{\mathrm{ABC}}$ & $3.57^{\mathrm{AB}}$ & $129.80^{\mathrm{A}}$ & $81.60^{\mathrm{BC}}$ \\
\hline $10^{-5} \mathrm{mM} / \mathrm{Lit}$ (PUT) & $219.10^{\mathrm{D}}$ & $165.00^{\mathrm{EF}}$ & $4.13^{\mathrm{ABC}}$ & $3.50^{\mathrm{AB}}$ & $105.80^{\mathrm{C}}$ & $73.30^{\mathrm{DE}}$ \\
\hline $10^{-7} \mathrm{mM} / \mathrm{Lit}(\mathrm{PUT})$ & $232.30^{\mathrm{BC}}$ & $180.50^{\mathrm{CD}}$ & $4.53^{\mathrm{AB}}$ & $3.27^{\mathrm{BC}}$ & $105.00^{\mathrm{C}}$ & $80.40^{\mathrm{BCD}}$ \\
\hline $10^{-3} \mathrm{mM} /$ Lit (PUT) + Multi-micronutrient & $245.80^{\mathrm{A}}$ & $179.30^{\mathrm{CD}}$ & $4.63^{\mathrm{A}}$ & $3.97^{\mathrm{A}}$ & $82.10^{\mathrm{E}}$ & $74.63^{\mathrm{CDE}}$ \\
\hline $10^{-5} \mathrm{mM} /$ Lit (PUT) + Multi-micronutrient & $199.40^{\mathrm{EF}}$ & $152.60^{\mathrm{F}}$ & $4.17^{\mathrm{ABC}}$ & $3.53^{\mathrm{AB}}$ & $95.53^{\mathrm{CD}}$ & $54.10^{\mathrm{F}}$ \\
\hline $10^{-7} \mathrm{mM} /$ Lit (PUT) + Multi-micronutrient & $196.50^{\mathrm{EF}}$ & $158.20^{\mathrm{EF}}$ & $4.15^{\mathrm{ABC}}$ & $3.10^{\mathrm{BC}}$ & $69.80^{\mathrm{F}}$ & $69.63^{\mathrm{E}}$ \\
\hline $10^{-6} \mathrm{mM} /$ Lit (PUT) + Multi-micronutrient & $209.10^{\mathrm{DE}}$ & $170.00^{\mathrm{DE}}$ & $3.80^{\mathrm{ABC}}$ & $2.80^{\mathrm{C}}$ & $84.95^{\mathrm{E}}$ & $80.30^{\mathrm{BCD}}$ \\
\hline $10^{-10} \mathrm{mM} /$ Lit (PUT) + Multi-micronutrient & $220.80^{\mathrm{CD}}$ & $234.90^{\mathrm{A}}$ & $3.53^{\mathrm{C}}$ & $3.23^{\mathrm{BC}}$ & $90.90^{\mathrm{DE}}$ & $67.00^{\mathrm{E}}$ \\
\hline $10^{-14} \mathrm{mM} /$ Lit (PUT) + Multi-micronutrient & $198.90^{\mathrm{EF}}$ & $200.10^{\mathrm{B}}$ & $4.17^{\mathrm{ABC}}$ & $3.70^{\mathrm{AB}}$ & $120.00^{\mathrm{B}}$ & $89.43^{\mathrm{A}}$ \\
\hline
\end{tabular}

Mean separation within treatments of the Valencia oranges according to L.S.D. at 0.05 level. 
In regard to the fruit peel thickness $(\mathrm{mm})$ data preformed that, there were significant differences between different treatments in this respect. The highest significant fruit peel thickness $(\mathrm{mm})$ were recorded for $10^{-3} \mathrm{mM} / \mathrm{Lit}$ (PUT) + Multi-micronutrient treatment (4.63and 3.97), respectively in both seasons Table (4).

Concerning the fruit juice volume $(\mathrm{cm})$ data preformed that, there were significant differences between the different treatments in this respect in both seasons. It was observed that fruit juice volume $(\mathrm{cm})$ in the Valencia oranges was ranged from 129.80 to 89.43 . fruit juice volume $(\mathrm{cm})$ was increased in treatment $10^{-3} \mathrm{~m} \mathrm{M} / \mathrm{Lit}$ (PUT) (129.80) and (89.43) in both seasons, respectively, whereas decreased in $10^{-7} \mathrm{mM} /$ Lit (PUT) + Multimicronutrient treatment (69.80) and $10^{-5} \mathrm{mM} /$ Lit (PUT) + Multi-micronutrient treatment (54.10) in both seasons, respectively Table (4).

b. Fruit chemical content:

1. Total soluble solids (TSS),TSS/acid ratio and Ascorbic acid (mg/100g juice):

As for the total soluble solids (TSS) percentage data preformed that, there were significant differences between the different treatments in this respect in both seasons. TSS percentage ranged from 13.53 to $11.53 .10^{-10} \mathrm{~m} \mathrm{M} / \mathrm{L}$ (PUT) + Multi-micronutrient treatment recorded the highest significant values of TSS $(12.47 \%)$ in the fruit juice of Valencia orange followed by the control treatment $(12.40$
$\%$ ) with no significant differences between them in the first season, meanwhile in the second season Multimicronutrient treatment recorded the highest significant values of TSS (13.53\%) shown in as shown in Table (5).

These results are in consistent with those reported by Zeerban et al. (1994), Qin and Qin (1996), and Sarrwy et al. (2012) they stated that spraying with boron achieved the highest total soluble solids concentration of orange and other fruit crops. Also, Malik and Singh (2006), Marzouk and Kassem (2010), Ayad et al. (2011), Kassem et al. (2011), Abd El-Migeed et al. (2013), Nikfar and Abdoosi (2013) and Raeisi et al. (2013) stated that polyamines (Putrescine) improved total soluble solids concentration of other fruit crops.

As related to the TSS/acid ratio data revealed that, there were significant differences between different treatments with respect to the TSS/acid ratio. TSS/acid ratio ranged from 17.07 to 12.67 . Control treatment recorded the highest significant values of TSS /acid ratio $(0.65 \%)$ in the fruit juice of Valencia orange in the first season, while in the second season $10^{-7} \mathrm{mM} / \mathrm{Lit}$ (PUT) treatment recorded the highest significant values (17.07) Table (5).

These data are in harmony with those reported by Ali et al. (2010) and Raeisi et al. (2013) they found that spraying putrescine at full bloom increased TSS/acid ratio of other fruit crops.

Table 5. Effect of multi-micronutrient and putrescine application alone or in combination at different concentrations on percentages of total soluble solids (TSS \%) and total acidity of Valencia oranges during 2015 and 2016 growing seasons.

\begin{tabular}{lcccccc}
\hline \multirow{2}{*}{ Treatments } & \multicolumn{3}{c}{ TSS (\%) } & \multicolumn{2}{c}{ TSS/acid ratio } & \multicolumn{2}{c}{ Ascorbicacid (mg/100g juice) } \\
\cline { 2 - 7 } & $\mathbf{2 0 1 5}$ & $\mathbf{2 0 1 6}$ & $\mathbf{2 0 1 5}$ & $\mathbf{2 0 1 6}$ & $\mathbf{2 0 1 5}$ & $\mathbf{2 0 1 6}$ \\
\hline Control & $12.40^{\mathrm{A}}$ & $11.07^{\mathrm{D}}$ & $17.03^{\mathrm{A}}$ & $13.80^{\mathrm{CDE}}$ & $54.50^{\mathrm{ABC}}$ & $55.37^{\mathrm{BC}}$ \\
Multi-micronutrient & $11.80^{\mathrm{AB}}$ & $13.53^{\mathrm{A}}$ & $14.93^{\mathrm{BCD}}$ & $12.67^{\mathrm{E}}$ & $50.50^{\mathrm{BCD}}$ & $56.50^{\mathrm{BC}}$ \\
$10^{-3} \mathrm{~m} \mathrm{M} /$ Lit (PUT) & $10.33^{\mathrm{D}}$ & $11.73^{\mathrm{BCD}}$ & $15.77^{\mathrm{BC}}$ & $15.53^{\mathrm{B}}$ & $49.13^{\mathrm{CD}}$ & $60.27^{\mathrm{B}}$ \\
$10^{-5} \mathrm{mM} /$ Lit (PUT) & $11.67^{\mathrm{B}}$ & $12.00^{\mathrm{BCD}}$ & $15.07^{\mathrm{BCD}}$ & $15.00^{\mathrm{BC}}$ & $49.60^{\mathrm{CD}}$ & $53.83^{\mathrm{C}}$ \\
$10^{-7} \mathrm{mM} /$ Lit (PUT) & $10.27^{\mathrm{D}}$ & $12.50^{\mathrm{BC}}$ & $14.97^{\mathrm{BCD}}$ & $17.07^{\mathrm{A}}$ & $46.67^{\mathrm{D}}$ & $56.50^{\mathrm{BC}}$ \\
$10^{-3} \mathrm{mM} /$ Lit (PUT) + Multi-micronutrient & $10.53^{\mathrm{D}}$ & $11.53^{\mathrm{CD}}$ & $14.73^{\mathrm{CD}}$ & $13.80^{\mathrm{CDE}}$ & $46.97^{\mathrm{D}}$ & $56.27^{\mathrm{BC}}$ \\
$10^{-5} \mathrm{mM} /$ Lit (PUT) + Multi-micronutrient & $10.80^{\mathrm{CD}}$ & $12.60^{\mathrm{B}}$ & $13.13^{\mathrm{E}}$ & $15.47^{\mathrm{B}}$ & $46.93^{\mathrm{D}}$ & $61.07^{\mathrm{B}}$ \\
$10^{-7} \mathrm{mM} /$ Lit (PUT) + Multi-micronutrient & $11.53^{\mathrm{B}}$ & $11.60^{\mathrm{BCD}}$ & $16.20^{\mathrm{AB}}$ & $15.30^{\mathrm{B}}$ & $52.50^{\mathrm{ABCD}}$ & $58.47^{\mathrm{BC}}$ \\
$10^{-6} \mathrm{mM} /$ Lit (PUT) + Multi-micronutrient & $11.40^{\mathrm{BC}}$ & $12.60^{\mathrm{B}}$ & $15.47^{\mathrm{BCD}}$ & $13.50^{\mathrm{DE}}$ & $57.13^{\mathrm{AB}}$ & $66.50^{\mathrm{A}}$ \\
$10^{-10} \mathrm{mM} /$ Lit (PUT) + Multi-micronutrient & $12.47^{\mathrm{A}}$ & $12.40^{\mathrm{BC}}$ & $15.13^{\mathrm{BCD}}$ & $14.43^{\mathrm{BCD}}$ & $49.07^{\mathrm{CD}}$ & $55.40^{\mathrm{BC}}$ \\
$10^{-14} \mathrm{mM} /$ Lit (PUT) + Multi-micronutrient & $11.53^{\mathrm{B}}$ & $12.40^{\mathrm{BC}}$ & $14.37^{\mathrm{D}}$ & $14.93^{\mathrm{BC}}$ & $58.40^{\mathrm{A}}$ & $53.80^{\mathrm{C}}$ \\
\hline
\end{tabular}

Mean separation within treatments of the Valencia oranges according to L.S.D. at 0.05 level.

Concerning the Ascorbic acid (mg/100g juice) data preformed that, there were significant differences between different treatments including control with respect to the vitamin C (mg/100 ml juice). Ascorbic acid (mg/100g juice) was noted to the tune of 66.50 to $46.67 .10^{-14} \mathrm{mM} / \mathrm{Lit}$ (PUT) + Multi-micronutrient treatment recorded the highest significant values of Ascorbic acid (mg/100g juice) (58.40) in the fruit juice of Valencia orange in the first season, while in the second season $10^{-6} \mathrm{mM} / \mathrm{Lit}$ (PUT) + Multi-micronutrient treatment recorded the highest significant values (66.50) Table (5).

These results were coincide with those obtained by Ahmed et al. (1993a \& b) who stated that spraying with boron achieved the highest vitamin $\mathrm{C}$ content of Balady mandarin fruits. In addition, Malik and Singh (2006), Ali et al. (2010), Marzouk and Kassem (2010) and Kassem et al. (2011) stated that" polyamines (Putresceine) improved on ascorbic acid content of other fruit crops.

With respect to fruit quality upon harvest, Dawood et al. (2000), EL-Baz (2003), Hafez and El Metwally (2007), Tariq et al. (2007), Abd El-Motty et al. (2010), Hanafy Ahmed et al. (2012), Sarrwy et al.(2012) Abd ElMotty and Orabi (2014), Salama (2015) and Gurung et al. (2016) found that spraying micronutrients (boron and zinc) have important role in fruit quality improvement in citrus and other fruit crops. Also, Khan et al. (2012) and Baghdady et al. (2014) indicated that foliar spraying with Chelated zinc and boron significantly increased fruit quality in orange and madarin fruits. Besides, Abd ElMigeed et al. (2013) found that polyamine (Putrescine) improved fruit quality in Amhat date palm. 
3. Effect of multi-micronutrient and putrescine application alone or in combination at different concentrations on fruit quality during storage periods (days) at room temperature:

a. Fruit weight loss percentage.

Concerning the fruit weight loss percentage data preformed that, there were significant differences between all treatments in this respect. The comparison means indicated that $10^{-3} \mathrm{~m} \mathrm{M} / \mathrm{Lit}$ (PUT) treatment as the highest of fruit weight loss $(27.69 \%)$ in the first season and $10^{-10} \mathrm{~m}$ $\mathrm{M} /$ Lit (PUT) + Multi-micronutrient treatment by $(22.01 \%)$ in the second season. Whereas, $10^{-5} \mathrm{mM} / \mathrm{Lit}$ (PUT) + Multimicronutrient treatment has least of fruit weight loss with $(7.70 \%)$ in the first season and $10^{-7} \mathrm{mM} /$ Lit (PUT) + Multimicronutrient treatment by $(4.61 \%)$ or $10^{-6} \mathrm{~m} \mathrm{M} / \mathrm{Lit}$ (PUT) + Multi-micronutrient by $(5.79 \%)$ in the second seasons presented in Table (6).

However, fruit weight loss percentage was significantly affected by the various storage period (days) in both seasons. The comparison means indicated that storage period (21 days) has highest of fruit weight loss (\%) (36.18 and $21.72 \%)$ followed by 14 days (26.00 and
$16.45 \%$ ) then 7 days (14.02 and $10.38 \%$ ) in both seasons, respectively.

Statistical analysis indicated significant differences for the interaction of various storage periods per days and all treatments. The highest fruit weight loss percentage achieved by storage period (21 days) $\times 10^{-3} \mathrm{~m} \mathrm{M} / \mathrm{Lit}$ (PUT) by $(47.76 \%)$ in the first season and treatment $10^{-5} \mathrm{~m} \mathrm{M} / \mathrm{Lit}$ (PUT) by $\left(32.71 \%\right.$ ) or $10^{-10} \mathrm{~m} \mathrm{M} /$ Lit (PUT) + Multimicronutrient by $(34.62 \%)$ in the second season with no significant differences between them.

These data are in harmony with those reported by Mirdehghan and Rahemi (2002), Serrano et al. (2003), Ramezanian et al. (2010), Malik and Singh (2005), Raeisi et al. (2013) and Archana et al. (2015) they stated that application of polyamines on storage life of Valencia orange and other fruit crops reduced weight loss of fruit. Also, Mirdehghan et al. (2007) pointed out that application of PUT reduced fruit weight loss during ripening as well as cold storage, which may be ascribed to consolidation or stabilization of both cell integrity and tissue permeability.

Table 6. Effect of multi-micronutrient and putrescine application alone or in combination at different concentrations on percentages of fruit weight loss during storage period (days) at room temperature of Valencia oranges during 2015 and 2016 seasons.

\begin{tabular}{|c|c|c|c|c|c|c|c|c|c|c|}
\hline \multirow{2}{*}{ Treatments } & \multicolumn{4}{|c|}{ Storage period (days) } & \multirow{2}{*}{ Mean } & \multicolumn{4}{|c|}{ Storage period (days) } & \multirow{2}{*}{ Mean } \\
\hline & $\mathbf{0}$ & 7 & 14 & 21 & & $\mathbf{0}$ & 7 & 14 & 21 & \\
\hline \multicolumn{6}{|c|}{ First season; 2015} & \multicolumn{5}{|c|}{ Second season; 2016} \\
\hline Control & $0.00^{\mathrm{n}}$ & $11.80^{\mathrm{kI}}$ & $17.91^{\mathrm{ij}}$ & $35.45^{\mathrm{b}-\mathrm{e}}$ & $16.54^{\mathrm{EF}}$ & $0.00^{\circ}$ & $15.78^{\mathrm{g}-\mathrm{k}}$ & $19.68^{d-g}$ & $23.56^{\text {cde }}$ & $15.01^{\mathrm{C}}$ \\
\hline Multi & $0.0^{\mathrm{n}}$ & $26.47^{\text {gh }}$ & $29.99^{\mathrm{efg}}$ & $34.49^{\mathrm{c}-\mathrm{f}}$ & $22.99^{\mathrm{BC}}$ & $0.00^{\circ}$ & $4.56^{\text {no }}$ & $11.63^{\mathrm{j}-\mathrm{m}}$ & $19.40^{\mathrm{d}-\mathrm{h}}$ & $9.14^{\mathrm{E}}$ \\
\hline $10^{-3 \mathrm{~m} \mathrm{M} / \mathrm{Lit}(\mathrm{PUT})}$ & $0.00^{\mathrm{n}}$ & $21.02^{\text {hi }}$ & $40.98^{\mathrm{b}}$ & $47.76^{\mathrm{a}}$ & $27.69^{\mathrm{A}}$ & $0.00 \mathrm{o}$ & $9.18^{\operatorname{lmn}}$ & $15.29^{\mathrm{g}-1}$ & $20.35^{\mathrm{d}-\mathrm{g}}$ & $11.46^{\mathrm{DE}}$ \\
\hline $10^{-5} \mathrm{mM} / \mathrm{Lit}(\mathrm{PUT})$ & $0.00^{\mathrm{n}}$ & $20.61^{\text {hi }}$ & $37.04^{\mathrm{bcd}}$ & $39.26^{\mathrm{bc}}$ & $24.48^{\mathrm{B}}$ & $0.00^{\circ}$ & $9.94^{\mathrm{k}-\mathrm{n}}$ & $27.06^{\mathrm{bc}}$ & $32.71^{\mathrm{a}}$ & $17.68^{\mathrm{B}}$ \\
\hline $10^{-7} \mathrm{~m}$ & $0.00^{\mathrm{n}}$ & $10.35^{\mathrm{kl}}$ & $16.02^{\mathrm{ijk}}$ & $31.64^{\mathrm{d}-\mathrm{g}}$ & $14.76^{\mathrm{F}}$ & $0.00^{\circ}$ & $10.21^{\mathrm{k}-\mathrm{n}}$ & $18.66^{\mathrm{d}-\mathrm{h}}$ & $26.70^{\mathrm{bc}}$ & $14.15^{\mathrm{CD}}$ \\
\hline PUT) + Multi-micronutrient & $0.00^{\mathrm{n}}$ & $2.19^{\mathrm{mn}}$ & $21.43^{\text {hi }}$ & $41.49^{b}$ & & $0.00^{\circ}$ & $10.01^{\mathrm{k}-\mathrm{n}}$ & $14.84^{\mathrm{g}-\mathrm{l}}$ & $17.52^{\mathrm{e}-\mathrm{j}}$ & $0.85^{\mathrm{E}}$ \\
\hline T) + Multi-micronutrient & $0.00^{\mathrm{n}}$ & $3.91^{\mathrm{mn}}$ & $10.25^{\mathrm{kl}}$ & $15.63^{\mathrm{ijk}}$ & $7.70^{\mathrm{G}}$ & $0.00^{\circ}$ & $13.38^{\mathrm{h}-1}$ & $17.05^{\mathrm{f}-\mathrm{j}}$ & $23.87^{\text {cd }}$ & $13.83^{\mathrm{CD}}$ \\
\hline+ Multi-micronutrient & $0.00^{\mathrm{n}}$ & $26.23^{\text {gh }}$ & $29.14^{\mathrm{fg}}$ & $35.83^{\text {b-e }}$ & $23.05^{\mathrm{BC}}$ & $0.00^{\circ}$ & $3.28^{\mathrm{O}}$ & $4.41^{\text {no }}$ & $9.76^{\mathrm{k}-\mathrm{n}}$ & $4.61^{\mathrm{F}}$ \\
\hline $10^{-6} \mathrm{mM} /$ Lit (PUT) + Multi-micronutrient & $0.00^{\mathrm{n}}$ & $6.91^{\mathrm{lm}}$ & $29.83^{\text {efg }}$ & $35.94^{\text {b-e }}$ & $18.42^{\mathrm{DE}}$ & $0.00^{\circ}$ & $3.33^{\mathrm{O}}$ & $6.53^{\mathrm{mno}}$ & $12.29^{\mathrm{i}-\mathrm{m}}$ & $5.79^{\mathrm{F}}$ \\
\hline $10^{-10} \mathrm{mM} /$ Lit (PUT) + Multi micronutrient & $0.00^{\mathrm{n}}$ & $10.36^{\mathrm{kl}}$ & $31.91^{\mathrm{d}-\mathrm{g}}$ & $41.33^{\mathrm{b}}$ & $21.15^{\mathrm{CD}}$ & $0.00^{\circ}$ & $22.53^{\mathrm{c}-\mathrm{f}}$ & $29.86^{\mathrm{ab}}$ & $34.62^{\mathrm{a}}$ & $1^{\mathrm{A}}$ \\
\hline $10^{-14} \mathrm{mM} /$ Lit (PUT) + Multi micronutrient & $0.00^{\mathrm{n}}$ & $14.34^{\mathrm{jk}}$ & $21.49^{\text {hi }}$ & $39.07^{\mathrm{bc}}$ & $18.98^{\mathrm{DE}}$ & $0.00^{\circ}$ & $11.97^{\mathrm{i}-\mathrm{m}}$ & $15.93^{\mathrm{g}-\mathrm{k}}$ & $18.07^{\mathrm{d}-\mathrm{i}}$ & $11.74^{\mathrm{DE}}$ \\
\hline Mean & $0.00^{\mathrm{D}}$ & $14.02^{\mathrm{C}}$ & $26.00^{\mathrm{B}}$ & $36.18^{\mathrm{A}}$ & & $0.00^{\mathrm{D}}$ & $10.38^{\mathrm{C}}$ & $16.45^{\mathrm{B}}$ & $21.72^{\mathrm{A}}$ & \\
\hline
\end{tabular}

Mean separation within treatments, storage periods of the Valencia oranges and for their interaction according to L.S.D. at 0.05 level.

\section{b. Fruit decay (\%).}

As for the fruit decay percentage data revealed that, there were significant differences between all treatments in this respect. The comparison means indicated that control treatment has highest of fruit decay (\%) by (32.53 and $30.34 \%$ ) in both seasons, respectively. Whereas, $10^{-}$ ${ }^{3} \mathrm{mM} /$ Lit $(\mathrm{PUT})+$ Multi-micronutrient treatment has least of fruit decay (\%) with (1.00 and $1.00 \%)$ in both seasons, respectively presented in Table (7).

Moreover, fruit decay percentage was significantly affected by the various storage periods (days) in both seasons. The comparison means indicated that storage period (21 days) has highest of fruit decay (\%) by $(14.50$ and $15.31 \%$ ) followed by 14 days by (10.07 and $12.23 \%)$ then 7 days by (3.00 and $4.05 \%)$ in both seasons, respectively.

Statistical analysis indicated significant differences for the interaction of various storage periods (days) and all treatments. The highest fruit decay percentage achieved by storage period ( 21 days) $\mathrm{x}$ control treatment by (70.87 and $69.44 \%$ ) in both seasons, respectively. Meanwhile $10^{-}$
${ }^{3} \mathrm{mM} /$ Lit (PUT) + Multi-micronutrient has least of fruit decay $(\%)$ by $(1.00$ and $1.00 \%)$ in both seasons, respectively.

These findings are in line with those reported by Porat et al. (2000), Plaza et al. (2003) and Kinary et al. (2005) who revealed that losses in stored orange fruit were mostly brought about by fungus attacks. Therefore, micronutrients increased resistance to disease (Tariq et al. 2007). Also, Polyamines increase the more longevity of fruits in storage and decrease damage of storage (Esanaashari and Zokaeekhosroshahi, 2008).

c. Total soluble solids (TSS \%).

In regard to the total soluble solids (TSS) percentage data preformed that, there were significant differences between all treatments in terms of total soluble solids percentage. The comparison means indicated that highest rate of total soluble solids percentage was related to the Multi-micronutrient treatment by $(12.57$ and $13.61 \%)$ in both seasons, respectively. While lowest rate was related to $10-7 \mathrm{mM} / \mathrm{Lit}$ (PUT) treatment by $(10.75 \%)$ in the first 
season and control treatment by $(12.43 \%)$ in the second seasons Table (8).

Furthermore, total soluble solids percentage was significantly affected by the various storage periods (days) in both seasons. The comparison means indicated that highest rate of total soluble solids percentage was related to the storage period (21 days) by (12.42 and $13.47 \%)$ followed by 14 days by (12.36 and $13.31 \%$ ) then 7 days by (12.13 and $12.65 \%)$ in both seasons, respectively.

Statistical analysis indicated significant differences for the interaction of various storage periods (days) and all treatments in the first season, whereas there were no significant differences in the second season. Highest rate of total soluble solids percentage was related to storage period (14 days) x Multi-micronutrient by $(13.00 \%)$ followed by
(21 days) $\times 10^{-5} \mathrm{mM} / \mathrm{Lit}$ (PUT) by (13.00\%) then (21 days) x $10^{-10} \mathrm{mM} /$ Lit (PUT) + Multi-micronutrient by $(13.07 \%)$ in the first season with no significant differences between them.

These results were coincide with those obtained by Raeisi et al. (2013) who indicated that the effect of spermidine on percentage of TSS was significant during storage period of Valencia orange fruits. Meanwhile, Khosroshahi and Ashari (2008) found out that there was low soluble solid content in putrescine treated apricot and peach fruits during storage than untreated fruits. In addition, Mirdehghan and Rahemi (2002) and Archana et al. (2015) reported that exogenous application of putrescine delayed changes in accumulation of soluble solid content in fruits of other fruit crops.

Table 7. Effect of multi-micronutrient and putrescine application alone or in combination at different concentrations on percentages of fruit decay during storage period (days) at room temperature of Valencia oranges during 2015 and 2016 seasons.

\begin{tabular}{|c|c|c|c|c|c|c|c|c|c|c|}
\hline \multirow{3}{*}{ Treatments } & \multicolumn{4}{|c|}{ Storage period (days) } & \multirow{2}{*}{ Mean } & \multicolumn{4}{|c|}{ Storage period (days) } & \multirow{2}{*}{ Mean } \\
\hline & $\mathbf{0}$ & 7 & 14 & 21 & & $\mathbf{0}$ & 7 & 14 & 21 & \\
\hline & \multicolumn{5}{|c|}{ First season; 2015} & \multicolumn{5}{|c|}{ Second season; 2016} \\
\hline Control & $0.00^{d}$ & $10.67^{\mathrm{cd}}$ & $47.57^{b}$ & $70.87^{\mathrm{a}}$ & $32.53^{A}$ & $0.00^{\mathrm{d}}$ & $7.33^{d}$ & $43.57^{b}$ & $69.44^{\mathrm{a}}$ & $30.34^{\mathrm{A}}$ \\
\hline Multi-micronutrient & $0.00^{\mathrm{d}}$ & $1.00^{\mathrm{d}}$ & $23.07^{\mathrm{c}}$ & $17.52^{\mathrm{cd}}$ & $10.65^{\mathrm{BC}}$ & $0.00^{\mathrm{d}}$ & $1.00^{\mathrm{d}}$ & $20.91^{\mathrm{cd}}$ & $17.00^{\mathrm{d}}$ & $9.89^{\mathrm{B}}$ \\
\hline $10^{-3 \mathrm{~m} \mathrm{M} / \mathrm{Lit}(\mathrm{PUT})}$ & $0.00^{\mathrm{d}}$ & $3.43^{\mathrm{d}}$ & $19.11^{\mathrm{cd}}$ & $23.12 \mathrm{c}$ & $11.66^{\mathrm{B}}$ & $0.00^{\mathrm{d}}$ & $14.0^{\mathrm{d}}$ & $36.67^{\mathrm{bc}}$ & $37.00^{\mathrm{bc}}$ & $22.17^{\mathrm{A}}$ \\
\hline $10^{-5} \mathrm{mM} / \mathrm{Lit}$ (PUT) & $0.00^{\mathrm{d}}$ & $3.70^{\mathrm{d}}$ & $9.44^{\mathrm{cd}}$ & $12.85^{\mathrm{cd}}$ & $6.74^{\mathrm{BCD}}$ & $0.00^{\mathrm{d}}$ & $3.23^{\mathrm{d}}$ & $8.24^{\mathrm{d}}$ & $12.25^{\mathrm{d}}$ & $6.18^{\mathrm{B}}$ \\
\hline $10^{-7} \mathrm{mM} / \mathrm{Lit}(\mathrm{PUT})$ & $0.00^{\mathrm{d}}$ & $1.00^{\mathrm{d}}$ & $1.00^{\mathrm{d}}$ & $2.52^{\mathrm{d}}$ & $1.37^{\mathrm{D}}$ & $0.00^{\mathrm{d}}$ & $1.00^{\mathrm{d}}$ & $1.00^{\mathrm{d}}$ & $1.78^{\mathrm{d}}$ & $1.19^{\mathrm{B}}$ \\
\hline $10^{-3} \mathrm{mM} /$ Lit (PUT) + Multi-micronutrient & $0.00^{\mathrm{d}}$ & $1.00^{\mathrm{d}}$ & $1.00^{\mathrm{d}}$ & $1.00^{\mathrm{d}}$ & $1.00^{\mathrm{D}}$ & $0.00^{\mathrm{d}}$ & $1.00^{\mathrm{d}}$ & $1.00^{\mathrm{d}}$ & $1.00^{\mathrm{d}}$ & $1.0^{\mathrm{B}}$ \\
\hline $10^{-5} \mathrm{mM} / \mathrm{Lit}(\mathrm{PUT})+$ Multi-micronutrient & $0.00^{\mathrm{d}}$ & $1.00^{\mathrm{d}}$ & $4.17^{\mathrm{d}}$ & $18.85^{\mathrm{cd}}$ & $6.25^{\mathrm{BCD}}$ & $0.00^{\mathrm{d}}$ & $1.00^{\mathrm{d}}$ & $3.13^{\mathrm{d}}$ & $17.33^{\mathrm{d}}$ & $5.61^{\mathrm{B}}$ \\
\hline $10^{-7} \mathrm{mM} / \mathrm{Lit}(\mathrm{PUT})+$ Multi-micronutrient & $0.00^{\mathrm{d}}$ & $3.84^{\mathrm{d}}$ & $2.42^{\mathrm{d}}$ & $1.00^{\mathrm{d}}$ & $2.96^{\mathrm{CD}}$ & $0.00^{\mathrm{d}}$ & $11.78^{\mathrm{d}}$ & $17.3^{\mathrm{d}}$ & $4.37^{\mathrm{d}}$ & $8.62^{\mathrm{B}}$ \\
\hline $10^{-6} \mathrm{mM} / \mathrm{Lit}(\mathrm{PUT})+$ Multi-micronutrient & $0.00^{\mathrm{d}}$ & $1.00^{\mathrm{d}}$ & $1.00^{\mathrm{d}}$ & $4.59^{d}$ & $1.89^{\mathrm{D}}$ & $0.00^{\mathrm{d}}$ & $1.00^{\mathrm{d}}$ & $1.00^{\mathrm{d}}$ & $3.84^{\mathrm{d}}$ & $1.71^{\mathrm{B}}$ \\
\hline $10^{-10} \mathrm{mM} /$ Lit $(\mathrm{PUT})+$ Multi-micronutrient & $0.00^{\mathrm{d}}$ & $5.43^{\mathrm{cd}}$ & $1.00^{\mathrm{d}}$ & $1.00^{\mathrm{d}}$ & $2.10^{\mathrm{D}}$ & $0.00^{\mathrm{d}}$ & $2.25^{\mathrm{d}}$ & $1.00^{\mathrm{d}}$ & $1.00^{\mathrm{d}}$ & $1.31^{\mathrm{B}}$ \\
\hline $10^{-14} \mathrm{mM} /$ Lit (PUT) + Multi-micronutrient & $0.00^{\mathrm{d}}$ & $1.000^{\mathrm{d}}$ & $1.00^{\mathrm{d}}$ & $2.63^{\mathrm{d}}$ & $1.40^{\mathrm{D}}$ & $0.00^{\mathrm{d}}$ & $1.00^{\mathrm{d}}$ & $1.00^{\mathrm{d}}$ & $3.44^{\mathrm{d}}$ & $1.61^{\mathrm{B}}$ \\
\hline Mean & $0.00^{\mathrm{B}}$ & $3.00^{\mathrm{B}}$ & $10.07^{\mathrm{A}}$ & $14.50^{\mathrm{A}}$ & & $0.00^{\mathrm{B}}$ & $4.05^{\mathrm{B}}$ & $12.23^{\mathrm{A}}$ & $15.31^{\mathrm{A}}$ & \\
\hline
\end{tabular}

Mean separation within treatments, storage periods of the Valencia oranges and for their interaction according to L.S.D. at 0.05 level.

Table 8. Effect of multi-micronutrient and putrescine application alone or in combination at different concentrations on percentages of total soluble solids (TSS \%) during storage period (days) at room temperature of Valencia oranges during 2015 and 2016 seasons.

\begin{tabular}{|c|c|c|c|c|c|c|c|c|c|c|}
\hline \multirow{3}{*}{ Treatments } & \multicolumn{4}{|c|}{ Storage period (days) } & \multirow{2}{*}{ Mean } & \multicolumn{4}{|c|}{ Storage period (days) } & \multirow{2}{*}{ Mean } \\
\hline & $\mathbf{0}$ & 7 & 14 & 21 & & $\mathbf{0}$ & 7 & 14 & 21 & \\
\hline & \multicolumn{5}{|c|}{ First season; 2015} & \multicolumn{5}{|c|}{ Second season; 2016} \\
\hline Control & $12.40^{\mathrm{a}-\mathrm{g}}$ & $12.30^{\mathrm{b}-\mathrm{h}}$ & $12.13^{\mathrm{c}-\mathrm{i}}$ & $12.80^{\mathrm{abc}}$ & $12.41^{\mathrm{AB}}$ & $11.07^{\mathrm{a}}$ & $12.67^{\mathrm{a}}$ & $12.93^{\mathrm{a}}$ & $13.07^{\mathrm{a}}$ & $12.43^{\mathrm{D}}$ \\
\hline Multi-mic & $11.80^{\mathrm{g}-1}$ & $12.80^{\mathrm{abc}}$ & $13.00^{\mathrm{a}}$ & $12.67^{\mathrm{a}-\mathrm{d}}$ & & $13.53^{\mathrm{a}}$ & $12.70^{\mathrm{a}}$ & $14.20^{\mathrm{a}}$ & $14.00^{\mathrm{a}}$ & $13.61^{\mathrm{A}}$ \\
\hline $10^{-3 \mathrm{~m} \mathrm{M} / \mathrm{Lit} \text { (PUT) }}$ & $10.33^{\mathrm{p}}$ & $11.83^{\mathrm{f}-\mathrm{l}}$ & $12.47^{\mathrm{a}-\mathrm{f}}$ & $11.67^{\mathrm{h}-\mathrm{l}}$ & & $11.73^{\mathrm{a}}$ & $12.40^{\mathrm{a}}$ & $12.47^{\mathrm{a}}$ & $14.27^{\mathrm{a}}$ & $12.72^{\mathrm{BCD}}$ \\
\hline $10^{-5} \mathrm{mM} / \mathrm{Lit}(\mathrm{PUT})$ & $11.67^{\mathrm{h}-1}$ & $11.97^{\mathrm{e}-\mathrm{k}}$ & $12.83^{\mathrm{ab}}$ & $13.00^{\mathrm{a}}$ & $12.37^{\mathrm{AB}}$ & $12.00^{\mathrm{a}}$ & $12.00^{\mathrm{a}}$ & $13.07^{\mathrm{a}}$ & $13.00^{\mathrm{a}}$ & $12.52^{\mathrm{CD}}$ \\
\hline $10^{-7} \mathrm{mM} / \mathrm{Lit}$ (PUT) & $10.27^{\mathrm{p}}$ & $10.47^{\mathrm{op}}$ & $11.27^{\mathrm{lmn}}$ & $11.00^{\mathrm{mno}}$ & $10.75^{\mathrm{D}}$ & $12.50^{\mathrm{a}}$ & $12.10^{\mathrm{a}}$ & $13.07^{\mathrm{a}}$ & $13.60^{\mathrm{a}}$ & $12.82^{\mathrm{BCD}}$ \\
\hline $10^{-3} \mathrm{mM} / \mathrm{Lit}(\mathrm{PUT})+$ Multi-micronutrient & $10.53^{\mathrm{op}}$ & $11.53^{\mathrm{i}-\mathrm{m}}$ & $12.67^{\mathrm{a}-\mathrm{d}}$ & $12.07^{\mathrm{d}-\mathrm{j}}$ & $11.70^{\mathrm{C}}$ & $11.53^{\mathrm{a}}$ & $12.00^{\mathrm{a}}$ & $13.07^{\mathrm{a}}$ & $14.07^{\mathrm{a}}$ & $12.67^{\mathrm{BCD}}$ \\
\hline $10^{-5} \mathrm{mM} /$ Lit (PUT) + Multi-micronutrient & $10.80^{\text {nop }}$ & $12.60^{\mathrm{a}-\mathrm{e}}$ & $12.80^{\mathrm{abc}}$ & $12.47^{\mathrm{a}-\mathrm{f}}$ & & $12.60^{\mathrm{a}}$ & $13.07^{\mathrm{a}}$ & $13.20^{\mathrm{a}}$ & $12.00^{\mathrm{a}}$ & $12.72^{\mathrm{BCD}}$ \\
\hline $10^{-7} \mathrm{mM} /$ Lit $(\mathrm{PUT})+$ Multi-micronutrient & $11.53^{\mathrm{i}-\mathrm{m}}$ & $12.63^{\mathrm{a}-\mathrm{e}}$ & $12.17^{\mathrm{b}-\mathrm{i}}$ & $12.73^{\mathrm{a}-\mathrm{d}}$ & $12.27^{\mathrm{AB}}$ & $11.60^{\mathrm{a}}$ & $12.80^{\mathrm{a}}$ & $13.60^{\mathrm{a}}$ & $13.47^{\mathrm{a}}$ & $12.87^{\mathrm{BC}}$ \\
\hline $10^{-6} \mathrm{mM} /$ Lit (PUT) + Multi-micronutrient & $11.40^{\mathrm{klm}}$ & $12.20^{\mathrm{b}-\mathrm{h}}$ & $12.60^{\mathrm{a}-\mathrm{e}}$ & $12.73^{\mathrm{a}-\mathrm{d}}$ & $12.23^{\mathrm{B}}$ & $12.60^{\mathrm{a}}$ & $13.00^{\mathrm{a}}$ & $13.20^{\mathrm{a}}$ & $13.27^{\mathrm{a}}$ & $13.02^{\mathrm{B}}$ \\
\hline $10^{-10} \mathrm{mM} / \mathrm{Lit}(\mathrm{PUT})+$ Multi-micronutrient & $12.47^{\mathrm{a}-\mathrm{f}}$ & $12.63^{\mathrm{a}-\mathrm{e}}$ & $11.47^{\mathrm{j}-\mathrm{m}}$ & $13.07^{\mathrm{a}}$ & $12.41^{\mathrm{AB}}$ & $12.40^{\mathrm{a}}$ & $13.40^{\mathrm{a}}$ & $14.40^{\mathrm{a}}$ & $13.80^{\mathrm{a}}$ & $13.50^{\mathrm{A}}$ \\
\hline $10^{-14} \mathrm{mM} / \mathrm{Li}$ & $11.53^{\mathrm{i}-\mathrm{m}}$ & $12.47^{\mathrm{a}-\mathrm{f}}$ & $12.60^{\mathrm{a}-\mathrm{e}}$ & $12.40^{\mathrm{a}-\mathrm{g}}$ & $12.25^{\mathrm{B}}$ & $12.40^{\mathrm{a}}$ & $13.00^{\mathrm{a}}$ & $13.20^{\mathrm{a}}$ & $13.60^{\mathrm{a}}$ & $13.05^{\mathrm{B}}$ \\
\hline Mean & $11.34^{\mathrm{C}}$ & $12.13^{\mathrm{B}}$ & $12.36^{\mathrm{A}}$ & $12.42^{\mathrm{A}}$ & & $12.18^{C}$ & $12.65^{\mathrm{B}}$ & $13.31^{\mathrm{A}}$ & $13.47^{\mathrm{A}}$ & \\
\hline
\end{tabular}

Mean separation within treatments, storage periods of the Valencia oranges and for their interaction according to L.S.D. at 0.05 level.

\section{d. TSS/acid ratio.}

Concerning the TSS/acid ratio data preformed that, there were significant differences between all treatments with respect to the TSS/acid ratio. The comparison means indicated that lowest rate of TSS/acid ratio was related in $10^{-10} \mathrm{mM} /$ Lit (PUT) + Multi-micronutrient with (14.19) treatment and highest rate was related in $10^{-6} \mathrm{mM} / \mathrm{Lit}$ $($ PUT) + Multi-micronutrient with (17.10) treatment in the first season. Whereas, Multi-micronutrient treatment has least of TSS/acid ratio with (12.43) and highest rate was related in $10^{-3} \mathrm{~m} \mathrm{M} / \mathrm{Lit}$ (PUT) with (17.72) treatment in the second season Table (9).

Moreover, TSS/acid ratio was significantly affected by the various storage periods (days) in the second season, while they were insignificant in the first season. The comparison means indicated that lowest rate of TSS/acid ratio was related in storage period (21 days) with (14.26) and highest rate was related in storage period (14 days) with (15.62) in the second season. 
Statistical analysis indicated significant differences for the interaction of various storage periods (days) and all treatments. Lowest rate of TSS/acid ratio was related in storage period (7 days) $\times 10^{-6} \mathrm{mM} /$ Lit (PUT) + Multimicronutrient with (14.53) and highest rate was related in storage period (7 days) $\times 10^{-10} \mathrm{mM} /$ Lit (PUT) + Multimicronutrient with (19.00) in the first season. Whereas, in the second season lowest rate of TSS/acid ratio was related in storage period (21days) $\mathrm{x}$ Multi-micronutrient with (9.40) and highest rate was related in storage period (7 days) $x$ Control with (22.20) in the second season.

These results are in accordance with those reported by Raeisi et al. (2013) who indicated that the effect of spermidine on percentage of TSS/acid was significant during storage period of Valencia orange fruits.

Table 9. Effect of multi-micronutrient and putrescine application alone or in combination at different concentrations on TSS/acid ratio during storage period (days) at room temperature of Valencia oranges during 2015 and 2016 seasons.

\begin{tabular}{|c|c|c|c|c|c|c|c|c|c|c|}
\hline \multirow{3}{*}{ Treatments } & \multicolumn{4}{|c|}{ Storage period (days) } & \multirow{2}{*}{ Mean } & \multicolumn{4}{|c|}{ Storage period (days) } & \multirow[b]{2}{*}{ Mean } \\
\hline & $\mathbf{0}$ & 7 & 14 & 21 & & $\mathbf{0}$ & 7 & 14 & 21 & \\
\hline & \multicolumn{5}{|c|}{ First season; 2015} & \multicolumn{5}{|c|}{ Second season; 2016} \\
\hline Control & $17.03^{\mathrm{bc}}$ & $15.03^{1-M}$ & $15.60^{\mathrm{e}-\mathrm{k}}$ & $14.97^{\mathrm{i}-\mathrm{m}}$ & $15.66^{\mathrm{C}}$ & $13.80^{1-0}$ & $22.20^{\mathrm{a}}$ & $16.30^{\mathrm{d}-\mathrm{i}}$ & $14.33^{j-0}$ & $16.66^{\mathrm{B}}$ \\
\hline Multi-micronutrient & $14.93^{i-m}$ & $15.00^{\mathrm{i}-\mathrm{m}}$ & $15.63^{\mathrm{e-k}}$ & $14.70^{\mathrm{j}-\mathrm{m}}$ & $15.07^{\mathrm{D}}$ & $12.67^{\circ}$ & $14.40^{j-0}$ & $13.27^{\mathrm{m}-\mathrm{O}}$ & $9.40^{\mathrm{p}}$ & $12.43^{\mathrm{D}}$ \\
\hline $10^{-3} \mathrm{~m} \mathrm{M} / \mathrm{Lit}$ (PUT) & $15.77^{\mathrm{d}-\mathrm{j}}$ & $14.57^{\mathrm{km}}$ & $14.30^{\mathrm{m}}$ & $15.43^{\mathrm{f}-\mathrm{m}}$ & $15.02^{\mathrm{D}}$ & $15.53^{\mathrm{f}-1}$ & $21.33^{\mathrm{ab}}$ & $16.80^{\mathrm{ch}}$ & $17.20^{\mathrm{c}-\mathrm{f}}$ & $17.72^{\mathrm{A}}$ \\
\hline $10^{-5} \mathrm{mM} / \mathrm{Lit}$ (PUT) & $15.07^{i-m}$ & $15.20^{\mathrm{h}-\mathrm{m}}$ & $16.77^{\mathrm{bcd}}$ & $15.60^{\mathrm{e-k}}$ & $15.66^{\mathrm{C}}$ & $15.00^{i-m}$ & $14.10^{j-0}$ & $15.40^{\mathrm{g}-1}$ & $14.03^{\mathrm{k}-\mathrm{o}}$ & $14.63^{\mathrm{C}}$ \\
\hline 10-7 $\mathrm{mM} /$ Lit (PUT) & $14.97^{i-m}$ & $15.80^{\mathrm{d}-\mathrm{j}}$ & $16.03^{\mathrm{c}-\mathrm{i}}$ & $15.23^{\mathrm{h}-\mathrm{m}}$ & $15.51^{\mathrm{CD}}$ & $17.07 \mathrm{c}-\mathrm{g}$ & $17.50^{\text {cde }}$ & $17.63^{\mathrm{cd}}$ & $14.07^{j-0}$ & $16.57^{\mathrm{B}}$ \\
\hline $10^{-3} \mathrm{mM} /$ Lit (PUT) + Multi-micronutrient & $14.73^{\mathrm{j}-\mathrm{m}}$ & $15.37^{g-m}$ & $15.17^{\mathrm{h}-\mathrm{m}}$ & $15.83^{\mathrm{d}-\mathrm{j}}$ & $15.27^{\mathrm{CD}}$ & 13.801-o & $17.43^{\text {cde }}$ & $18.17^{\mathrm{c}}$ & $15.60^{\mathrm{f-k}}$ & $16.25^{\mathrm{B}}$ \\
\hline $10^{-5} \mathrm{mM} /$ Lit (PUT) + Multi-micronutrient & $13.13^{\mathrm{n}}$ & $15.00^{\mathrm{i}-\mathrm{m}}$ & $15.00^{\mathrm{i}-\mathrm{m}}$ & $17.10^{\mathrm{bc}}$ & $15.06^{\mathrm{D}}$ & $15.47^{f-1}$ & $15.37^{\mathrm{g}-1}$ & $15.80^{\mathrm{ek}}$ & $13.77^{1-\mathrm{o}}$ & $15.10^{\mathrm{C}}$ \\
\hline $10^{-7} \mathrm{mM} /$ Lit (PUT) + Multi-micronutrient & $16.20^{\mathrm{ch}}$ & $16.60^{b-e}$ & $16.43^{b-g}$ & $16.40^{b-g}$ & $16.41^{\mathrm{B}}$ & $15.30^{\mathrm{h}-\mathrm{l}}$ & $16.33^{\mathrm{d}-\mathrm{i}}$ & $17.97^{\mathrm{cd}}$ & $14.73^{\mathrm{i}-\mathrm{n}}$ & $16.08^{\mathrm{B}}$ \\
\hline $10^{-6} \mathrm{mM} /$ Lit (PUT) + Multi-micronutrient & $15.47^{\mathrm{f}-1}$ & $19.00^{\mathrm{a}}$ & $17.43^{\mathrm{b}}$ & $16.50^{\mathrm{b}-\mathrm{f}}$ & $17.10^{\mathrm{A}}$ & $13.50^{\mathrm{mno}}$ & $16.40^{\mathrm{d}-\mathrm{i}}$ & $20.13^{\mathrm{b}}$ & $13.50^{\mathrm{mno}}$ & $15.88^{\mathrm{B}}$ \\
\hline $10^{-10} \mathrm{mM} /$ Lit $(\mathrm{PUT})+$ Multi-micronutrient & $15.13^{\mathrm{h}-\mathrm{m}}$ & $14.53^{\mathrm{km}}$ & $12.10^{\circ}$ & $15.00^{\mathrm{i}-\mathrm{m}}$ & $14.19^{\mathrm{E}}$ & $14.43^{j-0}$ & $17.23^{\mathrm{c}-\mathrm{f}}$ & $14.90^{\mathrm{i}-\mathrm{n}}$ & 13.13 no & $14.93^{\mathrm{C}}$ \\
\hline $10^{-14} \mathrm{mM} /$ Lit $(\mathrm{PUT})+$ Multi-micronutrient & $14.37^{\mathrm{lm}}$ & $15.77^{\mathrm{d}-\mathrm{j}}$ & $17.30^{\mathrm{b}}$ & $15.07^{\mathrm{i}-\mathrm{m}}$ & $15.63^{\mathrm{C}}$ & $14.93^{i-m}$ & $17.13^{\mathrm{c}-\mathrm{g}}$ & $15.83^{\mathrm{ej}}$ & $17.13^{\mathrm{c}-\mathrm{g}}$ & $16.26^{\mathrm{B}}$ \\
\hline Mean & $15.16^{\mathrm{B}}$ & $15.62^{\mathrm{A}}$ & $15.62^{\mathrm{A}}$ & $15.62^{\mathrm{A}}$ & & $14.68^{\mathrm{C}}$ & $17.22^{\mathrm{A}}$ & $16.56^{\mathrm{B}}$ & $14.26^{\mathrm{C}}$ & \\
\hline
\end{tabular}

Mean separation within treatments, storage periods of the Valencia oranges and for their interaction according to L.S.D. at 0.05 level.

\section{e. Ascorbic acid (mg/100g juice).}

As for the ascorbic acid $(\mathrm{mg} / 100 \mathrm{~g}$ juice)data revealed that, there were significant differences between all treatments in this respect. The comparison means indicated that Multi-micronutrient treatment has highest of ascorbic acid (mg/100g juice)with (69.13) and $10^{-7} \mathrm{mM} /$ Lit (PUT) treatment has least with (56.84) in the first season. Meanwhile, in the second season $10^{-3} \mathrm{~m} \mathrm{M} / \mathrm{Lit}$ (PUT) treatment has highest of ascorbic acid (mg/100g juice)with (62.92) and $10^{-5} \mathrm{mM} /$ Lit (PUT) treatment has least with (54.55) presented in Table (10).

Table 10. Effect of multi-micronutrient and putrescine application alone or in combination at different concentrations on ascorbic acid (V.C $\mathrm{mg} / 100 \mathrm{~g}$ juice)duringstorage period (days) at room temperature of Valencia oranges (season 2015).

\begin{tabular}{|c|c|c|c|c|c|c|c|c|c|c|}
\hline \multirow{3}{*}{ Treatments } & \multicolumn{4}{|c|}{ Storage period (days) } & \multirow{2}{*}{ Mean } & \multicolumn{4}{|c|}{ Storage period (days) } & \multirow{2}{*}{ Mean } \\
\hline & $\mathbf{0}$ & 7 & 14 & 21 & & $\mathbf{0}$ & 7 & 14 & 21 & \\
\hline & \multicolumn{5}{|c|}{ First season; 2015} & \multicolumn{5}{|c|}{ Second season; 2016} \\
\hline Control & $0.00^{\mathrm{n}}$ & $11.80^{\mathrm{KI}}$ & $17.91^{\mathrm{ij}}$ & $35.45^{\mathrm{b}-\mathrm{e}}$ & $16.54^{\mathrm{EF}}$ & $0.00^{\circ}$ & $15.78^{\mathrm{g}-\mathrm{k}}$ & $19.68^{\mathrm{d}-\mathrm{g}}$ & $23.56^{\text {cde }}$ & $15.01^{\mathrm{C}}$ \\
\hline Multi-micronutrient & $0.0^{\mathrm{n}}$ & $26.47^{\text {gh }}$ & $29.99^{\mathrm{efg}}$ & $34.49^{c-f}$ & $22.99^{\mathrm{BC}}$ & $0.00^{\circ}$ & $4.56^{\text {no }}$ & $11.63^{\mathrm{j}-\mathrm{m}}$ & $19.40^{\mathrm{d}-\mathrm{h}}$ & $9.14^{\mathrm{E}}$ \\
\hline $10^{-3 \mathrm{~m} \mathrm{M} / \mathrm{Lit}(\mathrm{PUT})}$ & $0.00^{\mathrm{n}}$ & $21.02^{\text {hi }}$ & $40.98^{\mathrm{b}}$ & $47.76^{\mathrm{a}}$ & $27.69^{\mathrm{A}}$ & $0.00 \mathrm{o}$ & $9.18^{\operatorname{lmn}}$ & $15.29^{\mathrm{g}-\mathrm{l}}$ & $20.35^{\mathrm{d}-\mathrm{g}}$ & $11.46^{\mathrm{DE}}$ \\
\hline $10^{-5} \mathrm{mM} / \mathrm{Lit}(\mathrm{PUT})$ & $0.00^{\mathrm{n}}$ & $20.61^{\mathrm{hi}}$ & $37.04^{\text {bcd }}$ & $39.26^{\mathrm{bc}}$ & $24.48^{\mathrm{B}}$ & $0.00^{\circ}$ & $9.94^{\mathrm{k}-\mathrm{n}}$ & $27.06^{\mathrm{bc}}$ & $32.71^{\mathrm{a}}$ & $17.68^{\mathrm{B}}$ \\
\hline $10^{-7} \mathrm{mM} / \mathrm{Lit}(\mathrm{PUT})$ & $0.00^{\mathrm{n}}$ & $10.35^{\mathrm{kl}}$ & $16.02^{\mathrm{ijk}}$ & $31.64^{\mathrm{d}-\mathrm{g}}$ & $14.76^{\mathrm{F}}$ & $0.00^{\circ}$ & $10.21^{\mathrm{k}-\mathrm{n}}$ & $18.66^{\mathrm{d}-\mathrm{h}}$ & $26.70^{\mathrm{bc}}$ & $14.15^{\mathrm{CD}}$ \\
\hline $10^{-3} \mathrm{mM} /$ Lit $(\mathrm{PUT})+$ Multi-micronutrient & $0.00^{\mathrm{n}}$ & $2.19^{\mathrm{mn}}$ & $21.43^{\mathrm{hi}}$ & $41.49^{\mathrm{b}}$ & $16.53^{\mathrm{EF}}$ & $0.00^{\circ}$ & $10.01^{\mathrm{k}-\mathrm{n}}$ & $14.84^{\mathrm{g}-1}$ & $17.52^{\mathrm{e}-\mathrm{j}}$ & $10.85^{\mathrm{E}}$ \\
\hline $10^{-5} \mathrm{mM} /$ Lit $(\mathrm{PUT})+$ Multi-micronutrient & $0.00^{\mathrm{n}}$ & $3.91^{\mathrm{mn}}$ & $10.25^{\mathrm{kl}}$ & $15.63^{\mathrm{ijk}}$ & $7.70^{\mathrm{G}}$ & $0.00^{\circ}$ & $13.38^{\mathrm{h}-1}$ & $17.05^{\mathrm{f}-\mathrm{j}}$ & $23.87^{\mathrm{cd}}$ & $13.83^{\mathrm{CD}}$ \\
\hline $10^{-7} \mathrm{mM} /$ Lit $(\mathrm{PUT})+$ Multi-micronutrient & $0.00^{\mathrm{n}}$ & $26.23^{\mathrm{gh}}$ & $29.14^{\mathrm{fg}}$ & $35.83^{\mathrm{b}-\mathrm{e}}$ & $23.05^{\mathrm{BC}}$ & $0.00^{\circ}$ & $3.28^{\mathrm{O}}$ & $4.41^{\text {no }}$ & $9.76^{\mathrm{k}-\mathrm{n}}$ & $4.61^{\mathrm{F}}$ \\
\hline $10^{-6} \mathrm{mM} / \mathrm{Lit}(\mathrm{PUT})+$ Multi-micronutrient & $0.00^{\mathrm{n}}$ & $6.91^{\mathrm{lm}}$ & $29.83^{\mathrm{efg}}$ & $35.94^{\mathrm{b}-\mathrm{e}}$ & $18.42^{\mathrm{DE}}$ & $0.00^{\circ}$ & $3.33^{\mathrm{O}}$ & $6.53^{\mathrm{mno}}$ & $12.29^{\mathrm{i}-\mathrm{m}}$ & $5.79^{\mathrm{F}}$ \\
\hline $10^{-10} \mathrm{mM} /$ Lit $(\mathrm{PUT})+$ Multi- micronutrient & $0.00^{\mathrm{n}}$ & $10.36^{\mathrm{kl}}$ & $31.91^{\mathrm{d}-\mathrm{g}}$ & $41.33^{\mathrm{b}}$ & $21.15^{\mathrm{CD}}$ & $0.00^{\circ}$ & $22.53^{\mathrm{c}-\mathrm{f}}$ & $29.86^{\mathrm{ab}}$ & $34.62^{\mathrm{a}}$ & $22.01^{\mathrm{A}}$ \\
\hline $10^{-14} \mathrm{mM} / \mathrm{Lit}(\mathrm{PUT})+$ Multi-micronutrient & $0.00^{\mathrm{n}}$ & $14.34^{\mathrm{jk}}$ & $21.49^{\mathrm{hi}}$ & $39.07^{\mathrm{bc}}$ & $18.98^{\mathrm{DE}}$ & $0.00^{\circ}$ & $11.97^{\mathrm{i}-\mathrm{m}}$ & $15.93^{\mathrm{g}-\mathrm{k}}$ & $18.07^{\mathrm{d}-\mathrm{i}}$ & $11.74^{\mathrm{DE}}$ \\
\hline Mean & $0.00^{\mathrm{D}}$ & $14.02^{\mathrm{C}}$ & $26.00^{\mathrm{B}}$ & $36.18^{\mathrm{A}}$ & & $0.00^{\mathrm{D}}$ & $10.38^{\mathrm{C}}$ & $16.45^{\mathrm{B}}$ & $21.72^{\mathrm{A}}$ & \\
\hline
\end{tabular}

Mean separation within treatments, storage periods of the Valencia oranges and for their interaction according to L.S.D. at 0.05 level.

Moreover, ascorbic acid (mg/100g juice) was significantly affected by the various storage periods (days) in both seasons. The comparison means indicated that storage period (21 days) has highest of ascorbic acid (mg/100g juice) with (71.26 and 64.57) in both season, respectively. While, storage periods (0 Time) and (14 days) has least with (51.04 and 53.74) in the first and second season, respectively.

Statistical analysis indicated significant differences for the interaction of various storage periods (days) and all treatments. Storage period (21days) x Multi-micronutrient has highest of ascorbic acid (V.C mg/100g juice)with (81.53) and storage period (0 Time) x $10^{-7} \mathrm{mM} / \mathrm{Lit}$ (PUT) has least with (46.67) in the first season. Meanwhile, in the second season storage period (21days) $\times 10^{-3} \mathrm{~m} \mathrm{M} / \mathrm{Lit}$ (PUT) has highest of ascorbic acid (V.C mg/100g juice)with (74.43) and storage period (7days) x $10^{-5} \mathrm{mM} / \mathrm{Lit}$ (PUT) has least with (47.40).

These results were in agreement with those obtained by Raeisi et al. (2013) who revealed that the effect of spermidine on percentage of vitamin $\mathrm{C}$ was significant during storage period of Valencia orange fruits. 
In terms of fruit quality during storage, Kramer et al. (1991) and Valero et al. (2002) speculated that, polyamines might maintain fruit quality by stabilizing cell walls, or by making cell walls less accesstible to wallsoftening enzymes. Reduction of apple fruit softening has been correlated with increasing the levels of endogenous polyamines (Kramer et al., 1989).

Putrescine application leads to changes in cell wall stability (Messiaen et al., 1997) by inhibition of the action of polygalacturonase and pectin methyl esterase involved in softening, and also cross-link pectin substances in the cell wall, producing rigidification and increasing fruit firmness (Martinez-Romero et al., 2002 and Perez-Vicente et al., 2002).Most of the research indicates that polyamines have a role in delaying ripening and senescence and ultimately its shelf-life in many fruits like plum (Serrano et al., 2003), mango (Aman and Zora, 2006 and Jawandha et al., 2012), kiwifruit (Jhalegar et al., 2012) and banana (Archana et al., 2015).

Torrigianiet al., (2004) indicated that Pre-storage PUT application has been reported to significantly suppress ethylene production and delay ripening in mango fruit. Also, Malik and Singh (2005) found that PAs act as antisenescence agents which delayed the softening in mango.

As well as, Khan et al. (2007) stated that PAs act as anti-senescence agents which delayed the softening in plum. In addition, Khan et al. (2008) mentioned that postharvest PUT application had been found to increase the total antioxidant activity in 'Angelino' plum. Also, Davarynejad et al. (2013) found that postharvest PUT application had been found to increase the total antioxidant activity in 'Lasgerdi' and 'Shahrodi' apricot.During postharvest polyamines have anti-senescence function by inhibition of the formation of enzymes essential to the synthesis of ethylene thus, reduced physiological weight loss, delaying ripening and extend fruit shelf life (Valero et al., 2002, Malik et al., 2003, Malik and Singh, 2005, Aman and Zora, 2006, Jawandha et al., 2012 and Mohammad et al., 2013).

\section{REFERENCES}

A.O.A.C. (2000). Associate of Official Analytical Chemists. Official Methods of Analysis $7^{\text {th }}$ ed. Washington D.C., USA.

A.O.A.C. (1985). Associate of Official Analytical Chemists. Official Methods of Analysis $14^{\text {th }} \mathrm{Ed}$.

Abd-El-Migeed, M.M.M., Mostafa, E.A.M., Ashour, N.E., Hassan, H.S.A., Mohamed, D.M. and Saleh, M.M.S. (2013). Effect of potassium and polyamine sprays on fruit set, fruit retention, yield and fruit quality of Amhat date palm. International Journal of agricultural research, $1-10$.

Abd-El-Motty, E.Z., Shahin, M.F.M., El-Shiekh, M.H. and Abd El-Migeed, M.M., M. (2010). Effect of algae extracts and yeast application on growth, nutritional status, yield and fruit quality of Keitte mango trees. Agric. Biol. J. N. Am. (3): $421-429$.

Abd El-Motty, E.Z. and Orabi, S.A. (2014). The beneficial effects of using zinc, yeast and selenium on yield, fruit quality and antioxidant defense systems in Navel orange trees grown under newly reclaimed sandy soil. Journal of Applied Sciences Research 9 (10): 6487-6497.
Abd-Allah, A.S. (2006). Effect of spraying some macro and micro nutrients on fruit set, yield and fruit quality of Washington Navel orange trees. J. Appl. Sci. Res. 2:1059-1063.

Ahmad, W., Niaz, A., Kanwal, S. and Rahmatullah, A. (2009). Role of boron in plant growth. A Review Journal Agric. Res., 47 (3): 329-338.

Ahmed, F.F. and Assy, K.G. and Ibrahiem, T.A. (1993 a). Possibility of controlling the alternate bearing in Balady mandarin trees (Citrus reticulate L.) by the application of $\mathrm{GA}_{3}$, boron and magnesium foliar sprays .Assiut J. of Agric. Sci., 23(3): 229-243.

Ahmed, F.F., Ali, A.H., Abdel-Aziz, F.H. and Ibrahim, T.A. (1993 b). Productivity of Balady mandarin trees an influenced by the application of Paclobutrozol and boron. Minia First Conf. for Hort. Crops (19-21 Oct.) 753-795.

Ali, E.A.M., Sarrwy, S.M.A. and Hassan, H.S.A. (2010). Improving Canino apricot trees productivity by foliar spraying with polyamines .J. Applied Sci. Res., 6:1359-1365.

Alloway, B.J. (2008). Zinc in soils and crop nutrition. International Zinc Association Brussel, Belgium. Anonymous. 2010. Agriculture Statistics of Pakistan. Ministry of Food, Agriculture and Livestock, Islamabad, Pakistan.

Aman, U. M. and Zora, S. (2006). Improved fruit retention yield and fruit quality in mango with exogenous application of polyamines. Scientia Hort.110: 16717.

Archana, T. J., Suresha, G. J. and Swamy, G. S. K. (2015). Influence of Exogenous Application of Putrescine on Ripening Changes in Banana cv. Grand Naine. Intl. J. Food. Ferment. Technol. 5(1), 53-58, June, 2015.

Ashraf, M.Y., Iqbal, N., Ashraf, M. and Akhter, J. (2014). Modulation of physiological and biochemical metabolites in salt stressed rice by foliar application of zinc. J. Plant Nutrition, 37: 447-457. August 2013 .ISSN 2250-3153.

Ayad, H.S., Yousef, A.R.M. and El-Moursi, A. (2011). Improving fruit and oil quality of picual olive through exogenous application of putrescine and stigmastero. N.Y. Sci. J., 4:40-45.

Badu, N. and Singh, A.R. (2001). Effect of foliar application of boron, zinc and copper on chemical characteristics of litchi fruits. Bioved, 12 (1/2): 4548.

Baghdady, G.A., Abdelrazik, A.M., Abdrabboh, G.A. and Abo-Elghit, A.A. (2014). Effect of foliar application of $\mathrm{GA}_{3}$ and some nutrients on yield and fruit quality of Valencia orange trees. Nature and Science, 12 (4):93-100.

Bai, J., Baldwin, E., Plotto, A., Manthey, J. A., McCollum, G., Irey, M. and Luzio, G. (2009). Influence of harvest time on quality of 'Valencia' oranges and juice. Proc. Fla. State Hort. Soc. 122: 308-315.

Bioniel, S.G. and Protacio, C.M. (2002). Potassium nitrate or urea can substitute for putrescine in improving fruit set in mango (Mangifera indica L. cv. Carabao.). Philippine Agric. Sci., 85:233-235. 
Brown, P. H. and Shelp, B. J. (1997). Boron mobility in plants. p. 85-101. In: R.W. Bell and B. Rerkasem (eds.). Boron in Soils and Plants. Kluwer Academic Publishers, Dordrecht, the Netherlands.

Davarynejad, G., Zarei, M., Ardakani, E., Nasrabadi, M.E. (2013). Influence of putrescine application on storability, postharvest quality and antioxidant activity of two Iranian apricot (Prunus armeniaca L.) cultivars. Not. Sci. Biol. 5, 212-219.

Dawood, S.A., Hamissa, A.M. and El-Hossing, A.A. (2000). Response of young Washington navel orange trees grown on slightly alkaline clayey soil to foliar application of Chelated micronutrients. J. Agric. Sci. Mansoura Univ., 25: 5229-5240.

Delgado, A., Benlloch, M. and Fernandez-Escobar, R. (1999). Mobilization of boron in olive trees during flowering and fruit development .Horticulture 291,616- 618 .

Dibble, A. R.G., Davies, P.J. and Mutschler, M.A. (1988). Polyamine content of long keeping Alcobacca tomato fruit. Plant Physiol., 86; 338-340.

Dickinson, K., O’Brien, J., Voet, L. and Edwards,T.(2003). Metalosate"zinc" in plant nutrition". Albion, 4(2):14.

Duncan, B. D. (1955). Multiple test range and multiple F tests. Biometries, 11-142.

EL-Baz, El-El, T. (2003). Effect of foliar sprays of Zinc and Boron on leaf mineral composition, yield and fruit storability of balady mandarin trees. J. Agric. Sci. Mansoura Univ., 28, 6911-6926.

Eskandari, S. (1999). Evaluation of the results of Amygdalus hybrids and introduce better clones in sahand horticultural station. First National Amygdalus Congress. [In Persian].

Esna-ashari, M. and Zokaeekhosroshahi, M. (2008). Polyamines and horticultural science. Publication of Bu-aliSina University. Hamedan. P. 293. floral and fruit development. JARQ 40 (1), 51-58.

Garcia-Papi, M.A. and Garcia-Martinez, J.L. (2003). Endogenous plant growth substances content in young fruits of seeded 'Clementine' mandarin as related to fruit set and development. HortScience 22:265-274.

Gurung, S., Mahato, S.K., Suresh, C. P. and Chetrri, B. (2016). Impact of foliar application of growth regulators and micronutrients on the performance of Darjeeling mandarin. American Journal of experimental agriculture.12 (4): $1-7$.

Hafez, M.O. and El-Metwally, I.M. (2007). Efficiency of zinc and potassium sprays alone or in combination with some weed control treatments on weeds growth, yield and fruit quality of Washington navel orange orchards. J. of Applied Sciences Research 3 (7): 613-621.

Hanafy Ahmed, A.H., Khalil, M.K., Abd EI-Rahman, A.M. and Hamed, N.A.M. (2012). Effect of zinc, tryptophan and indoleacetic acid on growth, yield and chemical composition of Valencia orange trees. Journal of Applied Sciences Research, 8(2): 901 -914.
Harhash, M.M. and Abdel Nasser, G. (2001). Response of Manzanillo olive cultivar to irrigation regime and boron fertigation under Siwa oasis conditions. Conf. of Sustainiable Agric. Develop. Fayoum Fac. of Agric. March 28-30, 1-15.

Hassan, H.S.A., Sarrwy, S.M.A. and Mostafa, E.A.M. (2010). Effect of foliar spraying with liquid organic fertilizer, some micronutrients and gibberellins on leaf minerals content, fruit set, yield, and fruit quality of "Hollywood" plum trees. Agriculture and Biology Journal of North America, 1, 638-643.

Jawandha, S.K., Gill, M.S., Singh, N., Gill, P.P.S. and Singh, N. (2012). Effect of post-harvest treatments of putrescine on storage of mango cv. Langra. Afr. J. Agric. Res 48, 6432-6436.

Jeyakumar, P., Durgadevi, D. and Kumar, N. (2001). Effect of zinc and boron fertilization on improving fruit yields in papaya (Carica papaya L.) cv. Co5. J. Plant Nut. Food Security \& Sustainability of agroecosystems. Kluwer Academic, Netherland. pp.356-357.

Jhalegar, M.J., Sharma, R.R., Pal, R.K. and Rana, V. (2012). Effect of postharvest treatments with polyamines on physiology and biochemical attributes kiwifruit (Actindiadeliciosa) cv. Allison. Fruits, 67(1).

Kamiab, F., Salehabad, M.H., Zamanibahramabadi, E. (2015). Evaluation the Effects of Foliar Treatments of Polyamines and Some Organic Acids on Quantitative and Qualitative Traits in Some Pistachio Cultivars. Journal of Nuts 6(2):131-142.

Kassem, H.A., Al-Obeed, R.S., Ahmed, M.A. and Omar, A.K.H. (2011). Productivity, fruit quality and profitability of Jujube trees improvement by preharvest application of agro-chemicals .Middle East J.Sci.Res., 9: 628- 637.

Kaur, H., Aulakh, P.S., Kapur, S.P. and Singh, S.N. (1990). Effect of growth regulators and micronutrients on granulation and fruit quality of sweet orange cv. Jaffa. Punjab Hort. J. 30 (1-4):13-19.

Kazi, S.S., Ismail, S. and Joshi, K.G. (2012). Effect of multimicronutrient on yield and quality attributes of the sweet orange, African Journal of Agricultural Research Vol.7 (29), 4118-4123.

Khan, A.S., Singh, Z. and Abbasi, N.A. (2007). Prestorage putrescine application suppresses ethylene biosynthesis and retards fruit softening during low temperature storage in 'Angelino' plum. Postharvest Biol. Technol. 46, 36 - 46.

Khan, A.S., Singh, Z., Abbasi, N.A., Swinny, E.E. (2008). Pre- or post-harvest applications of putrescine and low temperature storage affect fruit ripening and quality of Angelino' plum. J. Sci. Food Agric. 88, 1686-1695.

Khan, A.S., Ullah, W., Malik, A.U., Ahmad, R., Saleem, B.A. and Rajwana, I.A. (2012). Exogenous applications of boron and zinc influence leaf nutrient status, tree growth and fruit quality of feutrell's early (Citrus reticulata Blanco). Pak. J. Agri. Sci., 49(2): 113-119. 
Khosroshahi, M. R. Z. and Ashari, E. M. (2008). Effect of putrescine application on post-harvest life and physiology of strawberry, apricot, peach and sweet cherry fruits. J. Sci. Tech. Agric. Natur. Resourc. 45:219-230.

Kinary, P., Yildiz, M., Yildiz-Sen, F. and Mehmt, F. (2005). Integration of pre and postharvest treatment to Minimize Penicillium decay of samsuna mandarins Postharvest. Biol. Technol., 37:31 - 35 .

Kramer, G.F., Wang, C.Y. and Conway, W.S. (1989). Correlation of reduced softening and increased polyamines levels during low-oxygen storage of 'McIntosh' apples. J. Am. Soc. Hort. Sci. 114, 942946.

Kramer, G.F., Wang, C.Y. and Conway, W.S. (1991). Inhibition of softening by polyamine application in Golden Delicious and McIntosh apples. J. Am. Soc. Hort. Sci. 116, 813-819.

Malik, A.U., Singh, Z. and Dhaliwal, S. S. (2003). Exogenous application of putrescine affects mango fruit quality and shelf life. ActaHortic. 628, 121127.

Malik, A.U. and Singh, Z. (2005). Pre-storage application of polyamines improves shelf life and fruit quality of mango. J. Hort. Sci. Biotechnol., 80-363-369.

Malik, A.U. and Singh, Z. (2006). Improved fruit retention, yield and fruit quality in mango with exogenous application of polyamines. Sci. Hort., 110: 167-174.

Malik, R.P., Ahlawat, V. P. and Nain, A. S. (1999). Effect of foliar spray of urea and zinc sulphate on growth and fruiting of kinnow - mandarin hybrid. Haryana $\mathrm{J}$. Hort. Sci. 28 (1-2):33-34.

Marschner, H.C., (1996). Mineral nutrition of higher plants. Academic Press Limited Text Book 2nd Ed., pp: 864.

Martí, N., Mena, P., Cánovas, J.A., Micol, V. and Saura, D. (2007). Vitamin $C$ and the role of citrus juices as functional food .Nat Prod Commun. 4(5):677-700.

Martinez-Romero, D., Serrano, M., Carbonell, A., Brugos, L., Riquelme, F. and Valero, D. (2002). Effects of postharvest putrescine treatment on extending shelf life and reducing mechanical damage in apricot. J. Food Sci. 67, 1706 -1712.

Marzouk, H.A. and Kassem, H.A. (2010). Effect of Putrescine, $\mathrm{GA}_{3}, 2,4-\mathrm{D}$ and calcium on extending harvest season of Navel orange. Alexandria Sci. Exchange Journal, 31(2):193-199.

Mengel, K., Kosegarten, H., Kirkby, E.A. and Appel, T. (2001). Principles of Plant Nutrition. Springer, New York. p 807.

Messiaen, J., Cambier, P. and Van Cutsem, P. (1997). Polyamines and pectins. Plant Physiol., 113, 387395.

Mirdehghan, S.H., Rahemi, M., Castillo, S., MartínezRomero, D., Serrano, M. and Valero, D. (2007). Pre-storage application of polyamines by pressure or immersion improves shelf-life of pomegranate stored at chilling temperature by increasing endogenous polyamine levels. Postharvest Biol. Technol. 44, 26-33.

Mirdehghan, S.H. and Rahemi, M. (2002). Reducing of chilling damage of pomegranate (Punica granatum L.) with alternative heating. Iranian Journal of agriculture science 33(1).
Mohammad, R.S. (2013). Vacuum infiltration of polyamines reduces chilling injury and firmness loss of lemon stored at chilling temperature. Intl J. Agri. Crop Sci., $6(8): 445-451$.

Nikfar, S. and Abdoosi, V. (2013). Study on the effect of spermine and putrescine on free polyamines and TSS of apricot fruits (var: Shahroodi 48). ARPN Journal of Agricultural and Biological Science, 8 (6): 470476.

Obreza, T.A., Zekri, M., Hanlon, E.A., Morgan, K., Schumann, A. and Rouse, R. (2010). Soil and leaf tissue testing for commercial citrus production. University of Florida Extension Service. SL 253.04.

Perez-Vicente, A., Martinez-Romero, D., Carbonell, A., Serrano, M., Riquelme, F. and Guillen, F. (2002). Role of polyamines in extending shelf life and the reduction of mechanical damage during plum (Prunus salicina Lindl) storage. Postharvest Bio. Technol., 25:25-32.

Plaza, P., Usall, J., Torres, R., Lamarca, N., Asensio, A. and Vinas, I. (2003). Control of green and blue mold by curing on oranges during ambient and cold storage, Postharvest Biol. Technol., 28:195 - 198.

Porat, R., Daus, A., Weiss, B., Cohen, L., Fallik,E. and Droby, S. (2000). Reduction of postharvest decay inorganic citrus fruit by a short hot water brushing treatment. Postharv. Biol. Technol., 18:151 - 157.

Qin, X. and Qin, X.N. (1996): Foliar spray of B, Zn and Mg and their effect on fruit production and quality of Jincheng orange (Citrus sinensis). J. of Southwest Agric. Univ. 18 (1): 40 - 45.

Raeisi, M., Samani, R.B. and Honarvar, M. (2013). Application of exogenous spermidine treatment for reducing of chilling on fruit quality and quantity of Valencia orange var Olinda. Inl. J. Farm. Alli. Sci., 2: $1292-1297$.

Ram, R. A. and Bose, T. K. (2000): Effect of foliar application of magnesium and micronutrients on growth, yield and fruit quality of mandarin (Citrus reticulate Blanco). Indian journal of Horticulture. 57 (3): 215-220.

Ramezanian, A., Rahemi, M., Maftoun, M., Kholdebarin, B., Eshghi, S., Safizadeh, M. R. and Tavallali, V. (2010). The ameliorative effects of spermidine and calcium chloride on chilling injury in pomegranate fruits after long- term storage. Fruits 65:169- 178.

Rodríguez, V.A., Mazza, S.M., Martínez, G.C. and Ferrero, A.R. (2005). $\mathrm{Zn}$ and $\mathrm{K}$ influence in fruit sizes of Valencia orange Rev. Bras. Frutic. Jaboticabal - SP, 27(1): 132-135.

Sajid, M., Rab, A., Ali, N., Arif, M., Ferguson, L. and Ahmed, M. (2010). Effect of foliar application of Zn and $\mathrm{B}$ on fruit production and physiological disorders in sweet orange cv. Blood orange. Sarhad J. Agric. 26(3):355-360.

Salama, A.S.M. (2015). Effect of Algae Extract and Zinc Sulfate Foliar Spray on Production and Fruit Quality of Orange Tree cv. Valencia. IOSR Journal of Agriculture and Veterinary Science (IOSR-JAVS) Volume 8, PP 51-62.

Sarrwy, S.M.A., Gadalla, E.G. and Mostafa, E.A. M. (2012). Effect of calcium nitrate and boric acid sprays on fruit set, yield and fruit quality of cv. Amhat date palm. World Journal of Agricultural Sciences 8 (5): 506-515. 
Sayyad-Amin, P., Shahsavar, A.R., and Aslmoshtaghi, E. (2015). Study on foliar application nitrogen, boron and zinc on olive tree, Trakia Journal of Sciences, (2): $131-136$.

Serrano, M., Martinez-Romero, D., Guillen, F. and Valero, D. (2003). Effects of exogenous putrescine on improving shelf life of four plum cultivar Postharvest BiolTechnol 30:259-271.

Shoeib, M. M. and El-Sayed, A. (2003). Response of "Thompson Seedless" grape vines to the spray of some nutrients and citric acid. Minia J. Agric. Res. Dev. 23 (4): 681-698.

Sing, Z. and Janes, J. (2000). Regulation of fruit set and retention in mango exogenous Application of polyamines and their biosynthesis inhibitors. ActaHortic., 509: 675-680.

Slavki, P., Patrick, H. B., Joseph, H. C., Agnes, M. S. N., Christos, P., Hening, H. and James, S. (2001). Foliar boron application improves flower fertility and fruit set of olive Hort.Sci. 36 (4): 714 -716.

Snedecor, G. W. and Cochran, W. G. (1972). Statistical Methods. 7th Ed. The Iowa State Univ., Press Ames, Iowa, U.S.A., pp 593.

Swietlik, D. (1999): Zinc nutrition in horticultural crops. p. 109-118. In: J. Janick (ed.). Horticultural Reviews. John Wiley \& Sons, Inc.

Tariq, M., Sharif, M., Shah, Z. and Khan, R. (2007). Effect of foliar application of micronutrients on the yield and quality of sweet orange (Citrus sinensis L. Osbeck). Pakistan J. Biol. Sci., 10(11): 1823-1828.
Tiburcio, A.F. (1997). Polyamines inhibit lipid peroxidation in senescing Oat leaves. Plant Physiology. 99, 385390.

Tonon G., Kevers C., Faivre-Rampant O. and Grazianil M., Gaspar T. (2004). Effect of $\mathrm{NaCl}$ and mannitolisoosmotic stresses on prolin and free polyamine levels in embryogenic Fraxinusangustifolia callus. J. Plant Physiol., 161: 701-708.

Torrigiani, P., Bregoli, A.M., Ziosi, V., Scaramagli, S., Ciriaci, T., Rasori, A. and Costa, G. (2004). Preharvest polyamine and aminoethoxy vinyl glycine (AVG) applications modulate fruit ripening in Stark Red Gold nectarines (Prunus persica L Batsch). Postharvest Biol. Technol. 33, 293-308.

Valero, D., Martinez-Romero, D. and Serrano, M. (2002). The role of polyamines in the improvement of the shelf life of fruit. Trends in Food Science \& Technology. 13:228-234.

Yadav, V., Singh, P.N. and Yadav, P. (2013). Effect of foliar fertilization of boron, zinc and iron on fruit growth and yield of low-chill peach cv. Sharbati. International Journal of Scientific and Research Publications, 3, 1-6.

Zeerban, S.M., Salama, M. and El-Ansary, M. A. (1994). Effect of foliar application on fruit set, yield, fruit characteristics and leaf nutrients status of Balady and Succarie orange varieties in Kafr El-Sheikh Governorate . Egypt App. Sci. 9 (5): 759 -771.

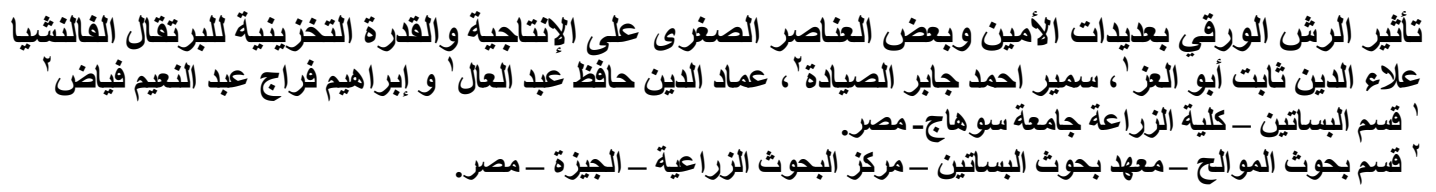

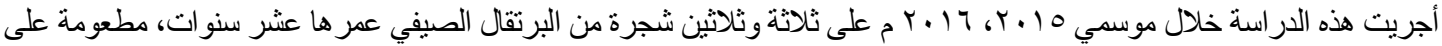

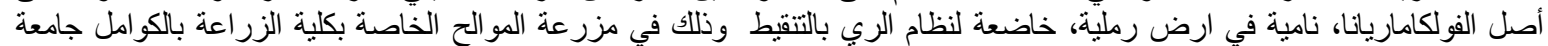

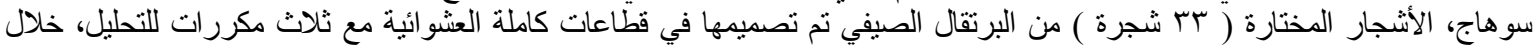

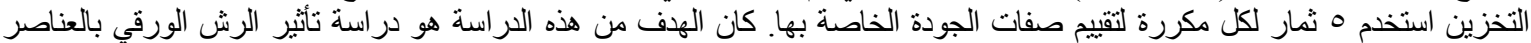

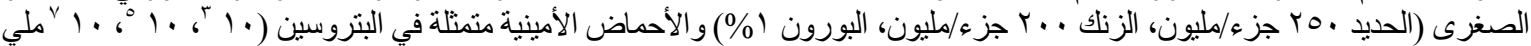

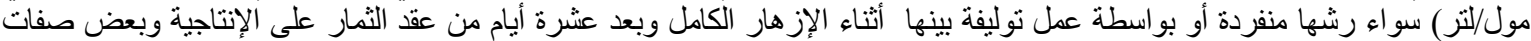

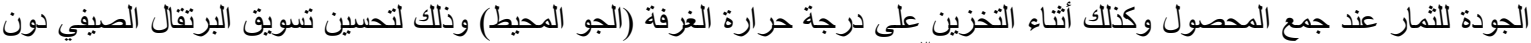

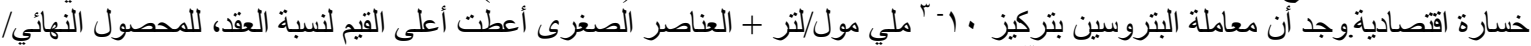

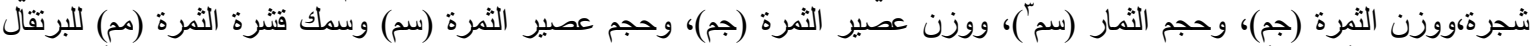

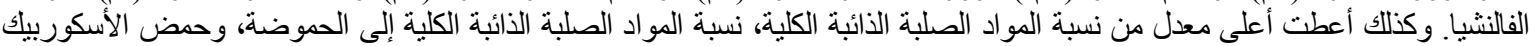

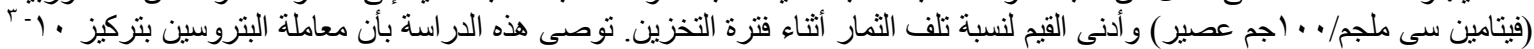

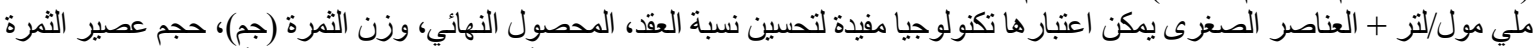

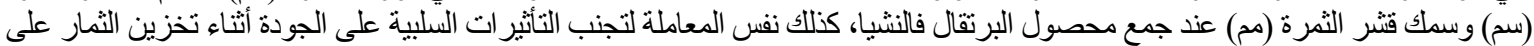

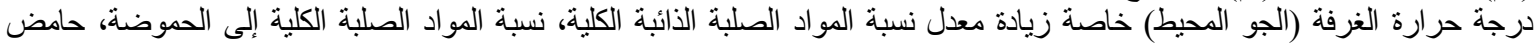
الأسكوربيك (فيتامين سى ملجم/ • • (جم عصير) لتحسين إمكانية تسويق البرتقال الفالنشيا دون خسارة القتصادية. 